\title{
The United Nations Security Council Sanctions and International Human Rights
}

\author{
Irène Couzigou*
}

\begin{abstract}
This article assesses whether the United Nations Security Council must respect human rights under international law when acting under Chapter VII of the United Nations Charter. It argues that the Security Council has to respect human rights enshrined in those human rights treaties drawn up under the United Nations' auspices and in non-peremptory customary international law, when this is not incompatible with the Security Council's objective of maintaining or restoring international peace and security. The analysis also argues however that the Security Council must comply with peremptory international human rights, with no exception. The paper concludes that Chapter VII action by the Security Council is limited only to a small extent by international human rights standards.
\end{abstract}

Keywords: United Nations Security Council, peace enforcement action, international human rights

\section{Introduction}

As the United Nations General Assembly stated, '... development, peace and security and human rights are interlinked and mutually reinforcing'. ${ }^{1}$ However, there may also exist a conflict between peace and security on the one hand, and respect for human rights on the other hand. The United Nations Security Council, in particular, may affect international human rights when adopting sanctions on the basis of Chapter VII of the United Nations Charter to maintain or restore international peace and security. The Security Council has decided on economic embargos against Member States whose conduct constituted a threat to the peace, a breach of the peace, or an act of aggression. Economic embargos have repercussions on the distribution of food and medicine, and therefore on the nutrition and health and even the survival, of the population of the targeted State. ${ }^{2}$ These measures affect many international human rights, especially economic and social rights - such as the right to an adequate standard of living, the right to be free from hunger and the right to health. ${ }^{3}$ Economic embargos may also have a negative im-

* Lecturer in Law at the University of Aberdeen Law School, UK, Email: irene.couzigou@abdn.ac.uk. Many thanks to Dr Angus Campbell for providing helpful comments on earlier drafts of this article.

1 World Summit Outcome, GA Res 60/1 (24 October 2005), para 9, UN Doc A/RES/60/1. See also SC Presidential Statement 2007/1 (8 January 2007), 1, UN Doc S/PRST/2007/1.

2 SC Res 752 Bosnia and Herzegovina (15 May 1992), paras 4-5, UN Doc S/RES/752 (establishing an economic embargo against the Federal Republic of Yugoslavia); SC Res 661 Iraq-Kuwait (6 August 1990), paras 3-4, UN Doc S/RES/661 (establishing an economic embargo against Iraq), completed by SC Res 687 Iraq-Kuwait (3 April 1991), para 1, UN Doc S/RES/687.

3 International Covenant on Economic, Social and Cultural Rights (hereafter: ICESCR) art 11-12 (adopted 16 December 1966, entered into force 3 January 1976) arts 11 and 12, 993 UNTS 7-8. 
pact on civil and political human rights, such as, in particular, on the right not to be subjected to an inhuman or degrading treatment or punishment or on the right to life. ${ }^{4}$ The Security Council has also established embargos on aeroplane flights that could equally have human rights consequences. ${ }^{5}$ For instance, the right to health may be affected if a prohibition on flying prevents a necessary medical transfer. ${ }^{6}$

The difficulty of reconciling the aim of the Security Council of the maintenance or re-establishment of international peace and security with human rights appears even more clearly when the Council adopts coercive measures against individuals, States' representatives or non-State actors. Those individuals are nominated on lists established by sanctions committees of the Security Council. ${ }^{7}$ The list administrated by the - so called Islamic State of Iraq and the Levant - ISIL (Da'esh) and Al-Qaida Sanctions Committee is the oldest one and has the broadest scope. Indeed, it concerns all members of ISIL or the Al-Qaida organisation and all associated individuals and entities. ${ }^{8}$ Security Council sanctions against individuals generally comprise an arms embargo, a travel ban and/or an assets freeze. ${ }^{9} \mathrm{~A}$ prohibition on travel could affect the right to family life if it prevented a person from joining his family. ${ }^{10} \mathrm{An}$ assets freeze can have negative effects on the right to an adequate standard of living and, more generally, on the right to property. ${ }^{11}$ Sanctions imposed by the Security Council on individuals, once they are listed on its sanctions lists, affect their civil rights. ${ }^{12}$ In conformity with article 14 of the ICCPR, '... in the determination ... of his rights and obligations in a suit at law, everyone shall be entitled to a fair and public hearing by a competent, independent and impartial tribunal established by law'.13 However, neither the listing of individuals on sanctions lists of the Security Council nor their de-listing from those lists is done after a fair trial according to that provision. ${ }^{14}$

4 International Covenant on Civil and Political Rights (hereafter: ICCPR, adopted 16 December 1966, entered into force 23 March 1976) art 6 and 7, 999 UNTS 174-175.

The right not to be subjected to an inhuman or degrading treatment or punishment or the right to life may be found to be infringed as a result of the lack of necessities such as food and medical supplies. The right to life requires States to take positive measures. See UNHRC 'General Comment 6 (Article 6)' (1982) para 5 UN Doc A/37/40 93.

5 SC Res 748 Libyan Arab Jamarihiya (31 March 1992), para 4, UN Doc S/RES/748 (imposing an aeroplane flight embargo in Libya).

6 ICESCR art 11 (n 3) 7.

7 Lists of the sanctions committees available at <https://www.un.org/sc/suborg/en/sanctions/information> accessed 14 June 2016.

8 List available at <https://www.un.org/sc/suborg/en/sanctions/1267/aq_sanctions_list> accessed 14 June 2016. Individuals and entities belonging or associated with ISIL were added to the list in December 2015.

9 Eg SC Res 1390 Situation in Afghanistan (16 January 2002), para 2, UN Doc S/RES/1390.

10 ICCPR art 17 (n 4) 177 .

11 ICESCR art 11 (n 3) 7 and Universal Declaration of Human Rights (adopted 10 December 1948) art 17, GA Res 217 A (III), UN Doc A/RES/217 (III).

12 The Court of First Instance of the European Communities and the UN Human Rights Committee rejected the classification of the sanctions of the then Al-Qaida and Taliban sanctions regime as criminal measures. Case T-47/03 Jose Maria Sison v Council of the European Union [2002] ECR II-00073 paras 101 and 129; UNHRC Communication no 1472/2006 Nabil Sayadi and Patricia Vinck v Belgium (2008) UN Doc CCPR/C/94/D/1472/2006 para 10.11 .

13 ICESCR art 14 (n 3) 176-177.

14 Except concerning the ISIL (Da'esh) and Al-Qaida sanctions list, the listing and de-listing of individuals are always decided by consensus by sanctions committees, composed by representatives of the Security Council members and politically influenced. 
Measures adopted by the Security Council against targeted individuals may have a direct impact on their human rights. For instance, the listing of individuals on a sanctions list by the Security Council has a negative impact on their right to due process. However, in general, the Security Council will not directly affect individuals and their human rights. Indeed, action by the Security Council needs generally to be implemented by Member States or sometimes by a regional organisation. The Security Council may have an impact on human rights indirectly, when its action is enforced by Member States or a regional organisation, without any margin of appreciation, and when this action contravenes those rights. For example, the freezing of assets of an individual decided on by the Security Council, enforced by Member States or by the European Union with no margin of discretion, has an impact on the right to property. Petitioners have argued on several occasions, before judicial or quasi-judicial bodies, that measures implementing Security Council resolutions, without discretion, are illegal because they are contrary to human rights or fundamental rights - in particular of a procedural nature. ${ }^{15}$ These courts or quasi courts did sometimes make a statement concerning the obligation of the United Nations Security Council to respect international human rights. For instance, the European Court of First Instance reviewed, incidentally, the validity of a Security Council resolution but only as regards peremptory international human rights. It did not state whether the Security Council also had otherwise to comply with human rights enshrined in treaties or in nonperemptory customary international law. ${ }^{16}$ More recently, the European Court of Justice asserted that the Security Council, in applying Chapter VII, must act 'in accordance with the purposes and principles of the United Nations, including respect for human rights'. ${ }^{17}$ It is not clear whether the Court referred to respect for human rights by the United Nations Security Council, or, to respect for human rights by United Nations Member States that has to be promoted by the Security Council. Furthermore, the Court did not specify which human rights exactly are at stake. This article aims to correct such imprecision. This paper will consider whether, and to what extent, the Security Council must respect international human rights when acting under Chapter VII of the United Nations Charter.

Part II of this study argues that the Security Council, acting on the basis of Chapter VII of the United Nations Charter, must observe human rights enshrined in human rights

15 See in particular Nabil Sayadi and Patricia Vinck (n 12); Case T-315/01 Yassin Abdullah Kadi v Council of the European Union and Commission of the European Communities [2005] ECR II-03649; Joined Cases C-402/05 P and C-415/05 P Yassin Abdullah Kadi and Al Barakaat International Foundation v Council of the European Union and Commission of the European Communities [2008] ECR I-06351; Case T-85/09 Yassin Abdullah Kadi v European Commission [2010] ECR II-05177; Joined Cases C-584/10 P, C-593/10 P and C-595/10 P European Commission, Council of the European Union, United Kingdom of Great Britain and Northern Ireland $v$ Yassin Abdullah Kadi [2013] ECR I-518; Nada $v$ Switzerland App no 10593/08 (ECtHR, 12 September 2012); Al-Dulimi and Montana Management Inc v Switzerland App no 5809/08 (ECtHR, 26 November 2013). For an analysis of reviews directed against measures implementing Security Council resolutions sanctioning individual non-State actors, Antonios Tzanakopoulos, 'Collective Security and Human Rights' in Erika de Wet \& Jure Widmar (eds), Hierarchy in International Law (OUP 2012) 42, 49-61.

16 Case T-306/01 Ahmed Ali Yusuf and Al Barakaat International Foundation v Council of the European Union and Commision of the European Communities [2005] ECR II-03533 para 277; Yassin Abdullah Kadi $v$ Council of the European Union and Commission of the European Communities (n 15) para 226; Case T-253/02 Chafiq Ayadi $v$ Council of the European Union [2006] ECR II-02139 para 116; Case T-49/04 Faraj Hassan $v$ Council of the European Union and Commission of the European Communities [2006] ECR II-00052 para 92.

17 European Commission, Council of the European Union, United Kingdom of Great Britain and Northern Ireland v Yassin Abdullah Kadi (n 15) para 104. 
treaties drawn up under the auspices of the United Nations or in non-peremptory customary international law, when this is not incompatible with the Council objective of maintaining or restoring international peace and security. The Security Council must do so when it implements itself its coercive action or when it requires from States the implementation, without any margin of appreciation, of its coercive action. Part III then contends that the Security Council must comply with peremptory human rights, with no exception. This obligation applies when the Security Council implements its measures or when it asks States to enforce them, with no margin of discretion. Part IV finally concludes that Chapter VII action by the Security Council is limited only to a small extent by international human rights standards.

\section{A Derogable Obligation of the Security Council to Respect Human Rights Contained in United Nations Human Rights Treaties or in Customary International Law}

\section{A. A Derogable Obligation to Respect Human Rights Contained in United Nations Human Rights Treaties}

\section{An Obligation to Promote and Encourage Respect for Human Rights}

As an organ of the United Nations, the Security Council is bound by the United Nations Charter and enjoys powers only insofar as they are conferred on it or implied by that treaty. ${ }^{18}$ Indeed, for the International Court of Justice, ' $[t]$ he political character of an organ cannot release it from the observance of the treaty provisions established by the Charter when they constitute limitations on its powers or criteria for its judgment'. ${ }^{19}$ Reference can also be made to a statement of the International Tribunal for the Former Yugoslavia: '[i]n any case, neither the text nor the spirit of the Charter conceives of the Security Council as legibus solutus (unbound by law)'.20 In particular, in accordance with article 24 paragraph 2 of the United Nations Charter, the Security Council '... shall act in accordance with the Purposes and Principles of the United Nations'.21

The purposes and principles of the United Nations correspond to the purposes and principles of articles 1 and 2 of the United Nations Charter. ${ }^{22}$ This was recognised by the International Court of Justice. Indeed, the Court stated that the United Nations must

18 Interpretation of the Agreement of 25 March 1951 between the WHO and Egypt (Advisory Opinion) [1980] IC] Rep 73, 89-90.

19 Conditions of Admission of a State to Membership in the United Nations (Article 4 of the Charter) (Advisory Opinion) [1948] IC] Rep 57, 64.

20 Prosecutor $v$ Dusko Tadić (Decision on the Defence Motion for Interlocutory Appeal on Jurisdiction) ICTY-94-1 para 28 (2 October 1995).

21 See also United Nations Conference on International Organization - Documents (United Nations \& Library of Congress 1945-1955) vol 12 518-519; Case Concerning Questions of Interpretation and Application of the 1971 Montreal Convention arising from the Aerial Incident at Lockerbie (Libyan Arab Jamahiriya $v$ United States of America) (Order) [1992] ICJ Rep 114, 171 (dissenting opinion of Judge Weeramantry).

22 United Nations Conference on International Organization - Documents (United Nations \& Library of Congress 1945-1955) vol 11387. 
respect the aim of the Charter to promote justice, that is referred to by article 1 of the Charter. ${ }^{23}$ Thus, as an organ of the United Nations, the Security Council must act in conformity with the Purposes and Principles of the first two articles of the United Nations Charter. Article 1 paragraph 2 states in particular that one purpose of the United Nations is '.. to develop friendly relations among nations based on respect for the principle of ... self-determination of peoples'. Development of the observance of the principle of self-determination of peoples is included in the more general purpose of the United Nations, under article 1 paragraph 3. In accordance with that provision, one aim of the United Nations is ' $[t] 0$ achieve international co-operation ... in promoting and encouraging respect for human rights and for fundamental freedoms for all'. Thus, the United Nations, including the Security Council, must promote and encourage respect for human rights by Member States. Article 55 refers to this obligation, stating that '...the United Nations shall promote ... universal respect for, and observance of, human rights and fundamental freedoms for all'. Article 13 paragraph 1 gives to the United Nations General Assembly the duty to initiate studies and make recommendations for the aim of '...assisting in the realization of human rights and fundamental freedoms'. Article 62 paragraph 2 gives a similar function to the Economic and Social Council: the Council '...may make recommendations for the purpose of promoting respect for, and observance of, human rights and fundamental freedoms for all'. Finally, in conformity with article 76 of the United Nations Charter, the trusteeship system shall '... encourage respect for human rights and for fundamental freedoms for all'. The expression 'human rights', as thus included in several provisions of the United Nations Charter, is not defined in the Charter. The participants in the preparatory work of the United Nations Charter wanted to include a human rights declaration in the Charter. However, due to a lack of time, such a declaration was not drafted and included in the Charter. ${ }^{24}$ The project was postponed for later on. It took the form of the Universal Declaration of Human Rights, adopted on 10 December 1948 by the United Nations General Assembly. ${ }^{25}$

The Security Council can participate, and has participated in this purpose of the United Nations of the promotion of and encouragement for respect for human rights. The Security Council thus can condemn infringement of human rights by Member States and ask for observance of human rights. It can do so in simple recommendations, and also in binding resolutions. ${ }^{26}$ Indeed, the Security Council may qualify grave violations of human rights linked to a present or impending armed conflict or other destabilisation of the security of a country or region as 'a threat to the peace'. It may then order the relevant

23 Effect of Awards of Compensation Made by the United Nations Administrative Tribunal (Advisory Opinion) [1954] IC] Rep 47, 57. See also Legal Consequences for States of the Continued Presence of South Africa in Namibia (South West Africa) notwithstanding Security Council Resolution 276 (1970) (Advisory Opinion) [1971] IC] Rep 16, 52; Case Concerning Application of the Convention on the Prevention and Punishment of the Crime of Genocide (Bosnia and Herzegovina $v$ Serbia and Montenegro) (Order) [1993] IC] Rep 325, para 101 (separate opinion of Judge Lauterpacht).

24 Ruth B Russel, A History of the United Nations Charter (The Brookings Institution 1958) 327-328.

25 Bardo Fassbender, 'Sources of human rights obligations binding the UN Security Council' in Peter HF Bekker, Rudolf Dolzer \& Michael Waibel (eds), Making Transnational Work in the Global Economy (CUP 2010) 71, 88-89.

26 Eg SC Res 1456 (20 January 2003), para 6, UN Doc S/RES/1456; SC Res 1653 (27 January 2006), preamble, UN Doc S/RES/1653. 
State to cease the violations. ${ }^{27}$ The Security Council has also created peacekeeping operations whose aim is, among others, the promotion and protection of human rights. ${ }^{28}$ Finally, the Security Council has established the international criminal tribunals for the Former Yugoslavia and Rwanda, competent to judge the criminal responsibility of representatives of those States for grave violations of international humanitarian law, that also correspond to grave infringements of human rights. ${ }^{29}$

The Security Council would not only be bound by the provisions of the Charter but also by any other international treaty to which the United Nations is a party. ${ }^{30}$ While the United Nations, including the Security Council, must promote and encourage respect for human rights, it is not itself a party to any human rights treaty. In general, international organisations are not party to human rights treaties. ${ }^{31}$ Indeed, accession to many human rights instruments is only open to States. Overall, when human rights treaties were drafted, it was not thought that international organisations could have a negative impact on individuals and their human rights. ${ }^{32}$

It is today no longer contested that an international organisation enjoys a separate international legal personality from its Member States and that it is not simply an extension of these States. ${ }^{33}$ In particular, the legal personality of the United Nations has been beyond doubt since the Reparations Advisory Opinion of the International Court of Justice. ${ }^{34}$ An international organisation does not act on behalf of its Member States but on its own behalf. Thus, several domestic jurisdictions have refused to see an international organisation as the agent of its Member States. ${ }^{35}$ Consequently, organs of an international

27 For instance, in Libya, in the preamble of resolution 1973, the Security Council condemned '... the gross and systematic violation of human rights, including arbitrary detentions, enforced disappearances, torture and summary executions', among the Libyan population, committed by the Libyan authorities and determined that the situation in Libya constituted a threat to international peace and security. SC Res 1973 (17 March 2011), preamble, UN Doc S/RES/1973.

$28 \mathrm{Eg}$ UN Operation in Côte d'Ivoire (UNOCI) that had to promote and protect human rights in Côte d'Ivoire. SC Res 2000 (27 July 2011), para 7, UN Doc S/RES/2000.

29 SC Res 827 (25 May 1993), para 2, UN Doc S/RES/827; SC Res 955 (8 November 1994), para 1, UN Doc S/RES/955.

30 Interpretation of the Agreement of 25 March 1951 between the WHO and Egypt (n 18) 89-90.

31 The European Union is an exception. It is party to the United Nations Convention on the Rights of People with Disabilities and it will probably become party to the Convention for the Protection of Human Rights and Fundamental Freedoms (European Convention on Human Rights). In regard to the relation between the European Union and the European Convention on Human Rights, see CJEU Opinion C-2/13 [2014] ECLI:EU:C:2014:2454.

32 Frédéric Mégret and Florian Hoffmann, 'The UN as a Human Rights Violator? Some Reflections on the United Nations Changing Human Rights Responsibilities' (2003) 25 Hum Rts Q 314, 315; Robert Kolb, Gabriel Porretto and Sylvain Vité, L'application du droit international humanitaire et des droits de I'homme aux organisations internationales (Bruylant 2005) 240-241.

33 Tarcisio Gazzini, 'Personality of international organizations', in Jan Klabbers \& Asa Wallendahl (eds), Research Handbook on the Law of International Organizations (Elgar 2011) 33, 33.

34 Reparation for Injuries Suffered in the Service of the United Nations (Advisory Opinion) [1949] IC] Rep $174,179$.

35 Concerning the Arab Organization for Industrialisation: Arab Organization for Industrialization, Arab British Helicopter Company and Arab Republic of Egypt $v$ Westland Helicopters Ltd, UA Emirates, Kingdom of Saudi Arabia and State of Qatar, Swiss Federal Supreme Court, 19 July 1988, 80 ILR 658 and the International Tin Council: JH Rayner (Mincing Lane) Ltd $v$ Department of Trade and Industry and others and Related Appeals, Maclaine Watson and Co Ltd v Department of Trade and Industry, Maclaine Watson and Co Ltd v International Tin Council, 26 October 1989, United Kingdom House of Lords, 81 ILR 681-682 (Lord Templeman) and 715-717 (Lord Oliver). 
organisation do not act on behalf of their members but on that of the organisation. ${ }^{36} \mathrm{An}$ international organisation continues to act on its own name even when its measures are adopted by unanimity of its Member States. Indeed, unanimity is only a procedural requirement and does not change the legal nature of the measures that are attributable to the organisation. ${ }^{37}$ Therefore, as an international organisation, the United Nations has its own rights and obligations that are distinct from those of its Member States. ${ }^{38}$ In particular, it does not have to respect international treaties just because they are binding upon its Member States. ${ }^{39}$ Thus, the Security Council, as an organ of the United Nations, is not automatically bound by the human rights treaties binding upon its Member States. This is implicitly acknowledged by the United Nations Charter. Its article 103 provides, in the event of a conflict, for the prevalence of the obligations of Member States under the Charter over their obligations under any other international agreement, including a human rights treaty. And it is widely recognised that this conflict rule covers conflicts with secondary norms derived from the Charter, in particular binding resolutions of the Security Council. ${ }^{40}$

In conclusion, in accordance with the United Nations Charter, the United Nations, including the Security Council, must promote and encourage respect for human rights by Member States. ${ }^{41}$ The United Nations itself is not a party to any human rights treaty and is not bound by human rights treaties simply because they are binding upon its Member States. Could an obligation of the United Nations, including the Security Council, to observe human rights treaties to which United Nations Member States are party be deduced from the United Nations obligation for promotion and encouragement of respect for human rights?

36 Acts of an organ of an international organisation are thus attributable to the Organisation. Art 6, para 1 Draft Articles on the Responsibility of International Organizations. GA Res 66/100 (9 December 2011) UN Doc A/RES/66/100.

According to Kelsen, the phrase used in art 24 UN Charter: 'the Security Council acts on behalf' of the UN Members, is 'legaly irrelevant and, in addition, incorrect'. Hans Kelsen, The Law of the United Nations (Stevens \& Sons Limited 1950) 280.

37 Daniel-Henri Vignes, 'Le principe de l'unanimité dans les organisations européennes' (1955) I Annuaire français de droit international 111, 112.

38 Niels Blokker, 'International Organizations and Their Members' (2004) 1 Int'L Org L Rev 139, $152-154$.

39 See generally Eric David, 'Le droit international applicable aux organisations internationales' in Dony Marianne (ed), Mélanges en hommage à Michel Waelbroeck (Bruylant 1999) 3, 18.

40 This is recognised by courts, in particular by the ICJ: Case Concerning Questions of Interpretation and Application of the 1971 Montreal Convention Arising from the Aerial Incident at Lockerbie ( $\mathrm{n} 21$ ) 126; by the Security Council itself: Andreas L Paulus \& Johann Ruben Lei $\beta$, 'Article 103' in Bruno Simma et al (eds), The Charter of the United Nations ( $3^{\text {rd }}$ edn, OUP 2012) vol II 2111, 2124; by the drafters of the United Nations Charter: United Nations Conference on International Organization Documents (United Nations \& Library of Congress 1945-1955) vol 13 717; by academia: Report of the study group of the ILC (prepared by M Koskenniemi), Fragmentation of International Law: Difficulties Arising from the Diversification and Expansion of International Law (13 April 2006), para 331, UN Doc A/CN4/L 682.

41 Emmanuel Decaux, 'De la promotion à la protection des droits de I'homme' in Société française de droit international (ed), La protection des droits de l'homme et l'évolution du droit international: actes du colloque de Strasbourg de 1997 (A Pedone 1998) 81, 82. 


\section{An Obligation to Respect in Principle Human Rights Contained in United Nations Human Rights Treaties}

The general principle of good faith implies that the parties to treaties interpret and implement those treaties in good faith. ${ }^{42}$ This general principle of international law is a paradigm in the international law of treaties and can also apply to the interpretation and application of the constituent treaties of international organisations by those organisations. As stated by the International Criminal Tribunal for the Former Yugoslavia, general principles of international law, as central values underpinning the international legal order, lay down 'an obligation that is incumbent, not only on States, but also on other international entities including the United Nations'. ${ }^{43}$ The United Nations, including the Security Council, is therefore bound by the general principle of good faith. Both must thus interpret the provisions of the United Nations Charter in good faith. ${ }^{44}$

The interpretation in good faith of a treaty corresponds to the reasonable interpretation of the terms of the treaty, taking into account the just expectations of the other party/parties. ${ }^{45}$ If the general principle of good faith is applied to article 1 paragraph 3 of the Charter, it can be argued that the obligation of the United Nations - and of its different organs - to promote and encourage respect for human rights includes the obligation to respect those human rights as much as possible. The latter obligation is relevant only for the United Nations activities which have an impact on individuals. This impact can be direct, for instance due to resolutions of the United Nations Security Council applied directly to individuals. The impact can also be indirect, for example due to measures that implement United Nations Security Council resolutions without any margin of appreciation. The United Nations has fulfilled its purpose of promoting and encouraging observance of human rights. It has done so in particular in developing a body of human rights treaties. For instance, the ICCPR and the ICESCR were drew up by the United Nations Economic and Social Council, then adopted by the United Nations General Assembly. ${ }^{46}$ Thus, if the United Nations interprets article 1 paragraph 3 of the Charter in good faith, as it should do, there is a legitimate expectation that it respects, to the greatest extent possible, human rights guaranteed by treaties prepared under its auspices, and in force, and that it asks States parties to those treaties, and United Nations members, to respect.

42 Vienna Convention on the Law of Treaties (adopted 23 May 1969, entered into force 27 January 1980) art 26 and 31, 1155 UNTS 339-340.

43 Dusko Tadić, 1995 (n 20) para 93.

44 Exposé oral de M le Professeur Spiropoulos, Effect of Awards of Compensation made by the United Nations Administrative Tribunal (Advisory Opinion) [1954] IC] Pleadings 351. Robert Kolb, La bonne foi en droit international public (Presses Universitaires de France 2000) 509; Elisabeth Zoller, La bonne foi en droit international public (A Pedone 1977) 190; Vera Gowlland-Debbas, 'Security Council Enforcement Actions and Issues of State Responsibility' (1994) 43 ICLQ 55, 94 (arguing that the principle of good faith limits the Security Council power in the implementation of art 39 of the UN Charter).

45 Award of the Tribunal of Arbitration in the Question Relating to the North Atlantic Coast Fisheries (Great Britain v United States of America) (7 September 1910) XI RIAA 173, 188; Case Concerning Rights of Nationals of the United States of America in Morocco (France $v$ United States of America) (merits) [1952] IC] Rep 176, 212; Case concerning the Aerial Incident of July 27th, 1955 (Israel $v$ Bulgaria) (merits) [1959] IC] Rep 127, 189 (joint dissenting opinion by Judges Hersch Lauterpacht, Wellington Koo \& Percy Spender). For academic study, see Markus Kotzur, 'Good Faith (Bona Fide)' in Rüdiger Wolfrum (ed), Max Planck Encyclopedia of Public International Law (2 ${ }^{\text {nd }}$ edn, North-Holland 2012) 508, para 20; Oliver Dörr, 'Article 31' in Oliver Dörr and Kirsten Schmalenbach (eds), Vienna Convention on the Law of Treaties (Springer 2012) 521, 541.

46 Rhona KM Smith, International Human Rights (6 $6^{\text {th }}$ edn, OUP 2014) 43. 
As indicated by August Reinisch, '[w]hen the United Nations - the major promoter of human rights in the international arena - takes enforcement action, it can be legitimately held to show respect for human rights in an exemplary fashion'. ${ }^{47}$ Referring to the work of human rights monitoring organs, the prior Secretary General of the United Nations, Kofi Annan, stated that: '[o]f course, the protection of human rights is not primarily the responsibility of this [Security] Council - it belongs to other United Nations bodies, whose work you do not need to duplicate. But there is a need to take into account the expertise of those bodies, and make sure that the measures you adopt do not unduly curtail human rights'. ${ }^{48}$ Support for the proposition that the United Nations as an organisation promoting and encouraging the observance of human rights obligations by Member States must itself observe, in principle, the same obligations, can be found in the Effect of Awards Advisory Opinion of the International Court of Justice. ${ }^{49}$ After having recognised that the United Nations is bound by the principle of justice, set up in article 1 of the United Nations Charter, it referred to a duty of that organisation to establish a tribunal for staff disputes. For the Court, it would '... hardly be consistent with the expressed aim of the Charter to promote freedom and justice for individuals ... that [the United Nations] should afford no judicial or arbitral remedy to its own staff for the settlement of any disputes which may arise between it and them'.50 Similarly, it would not be consistent with the expressed aim of the Charter to promote and encourage respect for human rights by Member States if the United Nations did not respect, as much as possible, those human rights guaranteed in treaties it initiated and that it wants Member States to observe.

The obligation of the United Nations, in particular of the United Nations Security Council, to respect in principle human rights set out in United Nations human rights treaties in force must be interpreted in the light of an evolving body of treaties. This obligation concerns today in particular those human rights enshrined in the two International Covenants of $1966 . .^{51}$ The ICCPR and the ICESCR are indeed the only general international human rights treaties prepared under the auspices of the United Nations. Furthermore, and more important, they are now ratified or acceded to by more than three-quarters of all States. ${ }^{52}$ Together with the Universal Declaration of Human Rights of 1948, the Covenants and their Protocols constitute the foundation of the United Nations system for the protection of human rights, the 'International Bill of Human Rights'.53

The implementation of Chapter VII of the United Nations Charter by the Security Council shows that the Council tries to respect human rights in its coercive action. It has declared that it will '... give consideration to' the potential impact of its mandatory measures on the civilian population, ' $\ldots$ in order to consider appropriate humanitarian ex-

47 August Reinisch, 'Developing Human Rights and Humanitarian Law Accountability of the Security Council for the Imposition of Economic Sanctions' 95 (2001) AJIL 851, 869.

48 Statement of the Secretary General, addressing the Council Meeting on Counter Terrorism (18 January 2002), available at <www.un.org/News/Press/docs/2002/sgsm8105.doc.htm> accessed 14 June 2016.

49 Reinisch (n 47) 857.

50 Effect of Awards of Compensation Made by the United Nations Administrative Tribunal (n 23 ) 57.

51 Both covenants refer in their preamble to the UN Charter obligation upon States 'to promote universal respect for, and observance of, human rights and freedoms'.

52 In June 2016, 168 States are party to the ICCPR and 164 to the ICESCR.

53 Smith (n 46) 37. 
emptions'. ${ }^{54}$ Along the same lines, it has affirmed '... the necessity for sanctions to contain adequate and effective exemptions to avoid adverse humanitarian consequences': that includes effects on human rights. ${ }^{55}$ The Security Council exempts certain goods from its economic embargoes for humanitarian purposes, in particular medical supplies and educational materials. ${ }^{56}$ Aeroplane flight embargos may also include derogations on the ground of humanitarian need. ${ }^{57}$ Security Council Committees, subsidiary organs created by the Council, are responsible for interpreting humanitarian exemptions set up in Security Council sanctions regimes. Humanitarian exemptions themselves are authorised by the relevant Security Council Committees or, under their supervision, by Member States of the United Nations. ${ }^{58}$ However, this case-by-case approach proved very often insufficient to cope with the severe humanitarian consequences of Security Council measures on broader parts of the population of targeted States, ${ }^{59}$ especially with respect to Iraq. ${ }^{60}$ This brought the five permanent members of the Security Council to confirm, in 1995, that the impact on human rights of future collective actions of the Council had to be minimized. ${ }^{61}$ In order to reduce unintended side effects of sanctions on the civilian population and also in order to enhance their effectiveness, comprehensive trade embargos were no longer enacted. New embargoes were often limited to specific goods such as arms, diamonds, and petroleum. ${ }^{62}$

Furthermore, the Security Council declared that sanctions should be '... carefully targeted in support of clear objectives and implemented in ways that balance effectiveness against possible adverse consequences'.63 The Security Council developed 'smart sanctions', targeted on State representatives responsible for any non-compliance with its decisions or on their family members. ${ }^{64}$ More recently, the Security Council also imposed

54 SC Res 1325 (31 October 2000), para 14, UN Doc S/RES/1325.

55 SC Res 1333 (19 December 2000), preamble, UN Doc S/RES/1333.

56 Eg SC Res 661 (6 August 1990), para 3, UN Doc S/RES/661; SC Res 687 (3 April 1991), para 20, UN Doc S/RES/687.

57 Eg SC Res 748 (31 March 1992), para 4 a, UN Doc S/RES/748; SC Res 1267 (15 October 1999), para 4 a, UN Doc S/RES/1267.

58 Paul Conlon, 'The Humanitarian Mitigation of UN Sanctions' (1996) 42 German Yearbook of International Law 249, 257-260; Djacoba Liva Tehindrazanarivelo, 'Le droit des Nations Unies et les limites au pouvoir de sanction du Conseil de sécurité' in Laura Forlati and Linos-Alexandre Sicilianos (eds), Economic Sanctions in International Law (Nijhoff 2014) 211, 260-261; Alexandros Kolliopoulos, 'Les comités des sanctions de I'Organisation des Nations Unies' in Laura Forlati \& Linos-Alexandre Sicilianos (eds), Economic Sanctions in International Law (Nijhoff 2014) 567, 579-581.

59 Report of the Secretary General on the Work of the Organization, GA Res 54/1 (31 August 1999), para 124, UN Doc A/54/1.

60 Report of the Sub-Commission on the Promotion and Protection of Human Rights (21 June 2000), para 63-67, UN Doc E/CN 4/Sub 2/2000/33. See also among an abundant literature: Eric Hoskins, 'The Humanitarian Impacts of Economic Sanctions and War in Iraq' in Thomas George Weiss et al (eds), Political Gain and Civilian Pain (Rowman \& Littlefield 1997) 91, 110-129; René Provost, 'Starvation as a Weapon: Legal Implications of the United Nations Food Blockade Against Iraq and Kuwait' (1992) 30 Colum J Transnat'l L 577, 583-588.

61 Letter dated 13 April 1995 from the Permanent Representatives of China, France, the Russian Federation, the United Kingdom of Great Britain and Northern Ireland and the United States of America to the United Nations addressed to the President of the Security Council. Annex, 2, UN Doc S/1995/300.

62 Eg SC Res 1343 (7 March 2001), para 6, UN Doc S/RES/1343 (prohibiting export of diamonds in Liberia).

63 SC Res 1730 (19 December 2006), preamble, UN Doc S/RES/1730. See also SC Press Statement 2006/28 (22 June 2006), 2, UN Doc S/PRST/2006/28.

64 Eg SC Res 841 (16 June 1993), para 8, UN Doc S/RES/841 (imposing the freezing of assets belonging to the government of Haiti or to the de facto authorities in Haiti or controlled by such government or 
sanctions on individuals and entities whose conduct cannot be attributed to a Member State. ${ }^{65}$ The Security Council aimed to reduce the impact of its sanctions on the targeted non-State actors. In particular, in order to take better consideration of the right to due process, the Security Council established a more independent procedure for de-listing members and entities from the ISIL (Da'esh) and Al-Qaida sanctions list than the procedure as regards other individuals' sanctions lists. The Ombudsperson, who is independent and impartial, prepares recommendations on de-listing requests for the ISIL (Da'esh) and Al-Qaida Sanctions Committee. ${ }^{66}$ Furthermore, the Security Council attempts to improve precision, fairness and transparency in the listing and de-listing procedures for individuals' sanctions lists. ${ }^{67}$ The Security Council also provides for humanitarian exemptions from sanctions against non-State actors. ${ }^{68}$

In parallel to its attempts to reduce the negative impact of its sanctions on human rights, the Security Council has affirmed that States should act in concordance with their human rights obligations when implementing its resolutions. For instance, in the context of the enforcement of counter-terrorist measures decided by the Security Council, the Council stated that: 'States must ensure that any measures taken to combat terrorism comply with all their obligations under international law, and should adopt measures in accordance with international law, in particular international human rights ....' ${ }^{69}$ Therefore, Security Council resolutions should be interpreted and implemented, to the greatest extent possible, in conformity with the human rights obligations of United Nations Member States. ${ }^{70}$

In conclusion, it is here argued that the Council must respect, with some exceptions, human rights guaranteed in treaties developed within the framework of the United Nations and in force. Such an obligation is deduced from a reasonable interpretation of the United Nations Charter that is supported by the practice of the Security Council on Chapter VII. The Security Council is bound by that obligation when it enforces coercive measures having an impact on individuals or when it requires from Member States to implement, without any margin of appreciation, coercive measures that affect individuals.

authorities), completed by SC Res 917 (6 May 1994), paras 3-4, UN Doc S/RES/917; SC Res 1127 (28 August 1994), para 4 a, UN Doc S/RES/1127 (imposing restrictions on the displacement of the senior officials of Uniăo Nacional para a Independência Total de Angola (UNITA) and of adult members of their immediate families in Angola), completed by SC Res 1173 (12 June 1998), para 11, UN Doc S/RES/1173; SC Res 1132 (8 October 1997), para 5, UN Doc S/RES/1132 (imposing travel prohibitions for members of the military junta and adult members of their families).

65 SC Res 1390 (16 January 2002), para 2, UN Doc S/RES/1390 (on enforcement measures against Usama bin Laden, members of the Al-Qaida organization, the Taliban, and individuals and entities associated with them).

66 Information on the de-listing procedure from the ISIL (Da'esh) \& Al-Qaida sanctions list, available at <https://www.un.org/sc/suborg/en/sanctions/1267/aq_sanctions_list/procedures-for-delisting> accessed 14 June 2016.

67 For instance, the Security Council established the Monitoring Team to assess and make recommendations regarding implementation of coercive measures against the Al-Qaida organization, the Taliban, and individuals and entities associated with them. SC Res 1617 (29 July 2005), para 19 and annex I, UN Doc S/RES/1617.

$68 \mathrm{Eg}$ the exemptions from the sanctions imposed on ISIL (Da'esh), Al-Qaida and associated individuals and entities, available at <https://www.un.org/sc/suborg/en/sanctions/1267/travel-ban> accessed 14 June 2016.

69 SC Res 1456 (20 January 2003), para 6, UN Doc S/RES/1456.

70 Al-Jedda $v$ The United Kingdom App no 27021/08 (ECtHR, 7 July 2011) para 105. See also in favour of such a presumption Nabil Sayadi and Patricia Vinck (n 12) 36 (Individual opinion Sir Nigel Rodley (concurring)). 
That obligation also applies when Member States chose to transfer the implementation of Security Council measures to a regional organisation, such as the European Union. Part II $\mathrm{C}$ of this article will explain below when and to what extent the Security Council is allowed to derogate or to require a derogation from human rights of United Nations human rights treaties.

\section{B. A Derogable Obligation to Respect Human Rights Contained in Customary International Law}

As subjects of international law created by States in the international legal order, international organisations must respect the general rules of that order. ${ }^{71}$ As stated by the International Court of Justice, '[i]nternational organizations are subjects of international law and, as such, are bound by any obligations incumbent upon them under general rules of international law ....' ${ }^{72}$ If international organisations perform the same acts as States, they have to follow the same customary rules regulating these acts than the States. ${ }^{73}$ The United Nations in particular is in principle bound by customary international law relevant to its activities. Numerous human rights obligations have passed into general international law. ${ }^{74}$ Thus, they may address not only States, but also the United Nations when it takes acts having a direct impact on individuals. Such is in particular the case when the United Nations Security Council lists individuals on a sanctions list. The listing act directly affects the right to a fair trial whose core content - determination of any criminal charge against an individual, or of his/her rights and obligations in a suit at law by an independent and impartial tribunal - can be seen has having a customary international legal nature. ${ }^{75}$

Since the United Nations, including the Security Council, is in principle bound by customary international law, in particular customary international human rights law, pertinent to its activities, it should not in principle adopt coercive measures whose implementation by Member States requires the violation of this law. This prohibition also applies when Member States transferred the implementation of Security Council measures to a regional organisation. Support for this rule can be found in article 15 of the Draft Articles on the Responsibility of International Organizations whose objective is to codify customary international law on the responsibility of international organisations. This provision states that: '[a]n international organization which directs and controls a State ... in the

71 Henry G Schermers and Niels M Blokker, International Institutional Law (5 ${ }^{\text {th }}$ edn, Martinus Nijhoff 2011) 835; Gérard Cahin, La coutume internationale et les organisations internationales (A Pedone 2001) 513-520; David (n 39) 20-21.

72 Interpretation of the Agreement of 25 March 1951 between the WHO and Egypt (n 18). See also Prosecutor $v$ André Rwamakuba (Decision on Appropriate Remedy) ICTR-98-44C-T para 48 (31 January 2007).

73 Albert Bleckmann, 'Zur Verbindlichkeit des allgemeinen Völkerrechts für internationale Organisationen' (1977) 107 Zeitschrift für ausländisches öffentliches Recht und Völkerrecht 107, 113-114.

74 Christian Tomuschat, Human Rights ( $3^{\text {rd }}$ edn, OUP 2014) 42-43.

75 The core components of the right to a fair trial are indeed recognised in numerous domestic legal orders as well as in regional and international human rights instruments, in particular in the ICCPR (art 14). See the study commissioned by the United Nations Office of Legal Affairs: Bardo Fassbender, 'Targeted Sanctions and Due Process' (2006) 1, 9-16, <www.un.org/law/counsel/Fassbender_study. pdf $>$ accessed 14 June 2016. It is however argued that the most fundamental guarantees of the right to a fair trial when the trial may lead to the death penalty are not only customary, but also peremptory. See infra part III B. 
commission of an internationally wrongful act by the State ... is internationally responsible for that act if: (a) the former organization does so with knowledge of the circumstances of the internationally wrongful act; and (b) the act would be internationally wrongful if committed by that organization'. ${ }^{76}$ According to the International Law Commission, 'direction and control' could encompass cases in which an international organisation takes a decision that binds its Members and that must be carried out without discretion. ${ }^{77}$ Thus, in conformity with article 15, the United Nations would in principle engage its responsibility if the Security Council adopted coercive measures whose implementation, without any margin of appreciation, necessitated that Member States violate customary international law, including customary international human rights law.

Since there is no hierarchy between treaties and that customary international law that is not peremptory, ${ }^{78}$ the United Nations Charter could authorise one or several of its organs to derogate from non-peremptory customary international law or to adopt measures whose enforcement by Member States involves deviation from that law in certain defined situations. In accordance with the second part of article 1 paragraph 1 of the United Nations Charter, the Security Council must act '... in conformity with the principles of justice and international law' when it brings '... adjustment or settlement of international disputes or situations which might lead to a breach of the peace'. The obligation to conform to the principles of international law is not however contained in the first part of article 1 paragraph 1 , which addresses the Council function to '... take effective collective measures for the prevention and removal of threats to the peace, and for the suppression of acts of aggression or other breaches of the peace'. It is generally accepted that the expression 'principles of international law' covers international treaties, customary international law, and general principles of international law as referred to in article 38 of the Statute of the International Court of Justice. ${ }^{79}$ Thus, it looks like the Security Council does not have to act in conformity with the principles of international law, including customary international law, when it adopts collective measures to be implemented by Member States in order to prevent and remove threats to the peace, acts of aggression or other breaches of the peace. The Security Council seems to be allowed to require from Member States that they derogate from customary international law in the implementation of its Chapter VII measures. ${ }^{80}$ This literal interpretation of article 1 paragraph 1 appears more clearly in the Spanish version of the Charter. It differentiates with the coordination conjunction 'and' (' $y$ ') and with a semicolon between the objective of the maintenance of international peace and security by the Security Council and the aim of

76 Art 15 Draft Articles on the Responsibility of International Organizations (n 36). See also art 17 of the Draft on the circumvention by an international organisation of international obligations. In accordance with art 17, an international organisation incurs international responsibility even if it adopts a decision binding a Member State to commit an act that is not wrongful for the State, but would be wrongful if committed by the organisation.

77 Art 15 Draft Articles on the Responsibility of International Organizations and its commentary ( $n$ 36).

78 Since a peremptory norm of general international law is a norm accepted by the international community of States from which no derogation is permitted, it must be a customary norm. Indeed, a customary norm is 'evidence of a general practice accepted as law' by the international community of States, in conformity with art 38 of the IC] Statute.

79 Rüdiger Wolfrum, 'Article $1^{\prime}$ in Bruno Simma et al (eds), The Charter of the United Nations (3 ${ }^{\text {rd }}$ edn, OUP 2012) vol I 107, 113-114.

80 The ICTY assumed the Security Council power of deviation from customary international law. Prosecutor v Dusko Tadić (Judgment) ICTY-94-1-A para 296 (July 15 July 1999). 
the peaceful resolution of international disputes by the Security Council. Only the later aim must conform to principles of international law. ${ }^{81}$ The preparatory work confirms that the omission of the 'principles of justice and international law' as a legal standard for peace enforcement action of the Security Council was intentional. During the deliberations of the San Francisco conference, it was proposed that article 1 paragraph 1 be amended so as to read, '... to maintain international peace and security, in conformity with the principles of justice and international law'. This motion was however rejected. ${ }^{82}$

The reason for the possible derogation by Member States from customary international law when implementing Chapter VII Security Council resolutions lies in the necessity for the efficiency of the Council coercive peace-keeping action. In accordance with article 1 paragraph 1 of the United Nations Charter, measures undertaken to maintain international peace and security must be 'effective'. That the Security Council can require from Member States that they depart from general international law when implementing its mandatory measures flows from the purpose of those measures. Without the ability of Member States to deviate from general international law in enforcing Security Council resolutions, the Council would not be able to act efficiently in the interests of international peace and security. ${ }^{83}$

In practice, the implementation by Member States of Security Council resolutions often necessitates that Member States deviate from customary international law. ${ }^{84}$ As an organ of the United Nations, the Security Council can of course interpret the constituent treaty of that organisation. ${ }^{85}$ However, only those interpretations of the Charter supported by a majority of the United Nations Member States are authoritative. Indeed, an international organisation is a derivative subject of international law and possesses only those powers conferred on it by the constituent treaty ratified by the Member States. Although an international organisation is allowed to interpret its constituent instrument, it is not competent to impose interpretations objected to by a majority of its Member States. ${ }^{86}$ United Nations Member States do not contest the capacity of the Security Coun-

81 The Spanish version reads: 'Los Propósitos de las Naciones Unidas son: 1. Mantener la paz y la seguridad internacionales, y con tal fin: tomar medidas colectivas eficaces para prevenir y eliminar amenazas a la paz, y para suprimir actos de agresión uotros quebrantamientos de la paz; y lograr por medios pacíficos, y de conformidad con los principios de la justicia y del derecho internacional, el ajuste o arreglo de controversias o situaciones internacionales susceptibles de conducir a quebrantamientos de la paz'. (emphasis added) The Spanish version is authoritative as well as the Chinese, French, Russian and English texts. UN Charter, art 111.

82 United Nations Conference on International Organization - Documents (United Nations \& Library of Congress 1945-1955) vol 6318 and 702.

For academic study, see Terry D Gill, 'Legal and Some Political Limitations on the Power of the UN Security Council to Exercise its Enforcement Powers Under Chapter VII of the Charter' (1995) 26 NYIL 33, 65-68.

83 Erika de Wet, The Chapter VII Powers of the United Nations Security Council 182 (Hart Publishing 2004); Gill (n 82) 62. See also Case Concerning Questions of Interpretation and Application of the 1971 Montreal Convention arising from the Aerial Incident at Lockerbie (Libya $v$ United States $v$ America) (merits) [1988] IC] Rep 115, 167 (dissenting opinion of Judge Schwebel).

84 The ICTY has recognised that 'it is open to the Security Council ... to adopt definitions of crimes in the [ICTY] Statute which deviate from customary international law'. Dusko Tadić, 1999 (n 80) para 296. See also Nico Krisch, 'Introduction to Chapter VII: The General Framework' in Bruno Simma et al (eds), The Charter of the United Nations ( $3^{\text {rd }}$ edn, OUP 2012) vol II 1237, 1257.

85 Certain Expenses of the United Nations (Article 17, Paragraph 2, of the Charter) (Advisory Opinion) [1962] IC] Rep 151, 159-161.

86 United Nations Conference on International Organization - Documents (United Nations \& Library of Congress 1945-1955) vol 13 720. See also Legal Consequences for States of the Continued Presence 
cil to adopt measures whose implementation involves the deviation from non-peremptory customary international law. ${ }^{87}$ The interpretation made by the Security Council of article 1 paragraph 1 of the United Nations Charter, in conformity with which it can impose to Member States a derogation from non-peremptory customary international law, should thus be considered as authoritative.

It is therefore concluded here that the Security Council may ask Member States to depart from non-peremptory customary international law, when they implement its Chapter VII action. This conclusion also applies when Member States transferred the implementation of Security Council action to a regional organisation, such as the European Union. If the Security Council is allowed to require that Member States derogate from non-peremptory customary international law binding upon them, it must a fortiori also be authorised to disregard non-peremptory customary international law directly binding upon it. The objective is the same: to lead to a greater efficiency of the Security Council in maintaining or restoring international peace and security. Thus, the Security Council may adopt measures whose implementation by other subjects than the United Nations involves the deviation from general international human rights law that is not peremptory, or the Security Council may deviate from that law itself.

The Council may derogate from non-peremptory customary international law, including customary international human rights law, but only to some extent. Similarly, it is submitted that the Security Council can ask Member States to derogate from non-peremptory customary international law, for instance from customary international human rights law, only within certain limits. These positions are confirmed by the preparatory work of the United Nations Charter. The committee dealing with the preparatory work on the preamble, purposes and principles of the United Nations Charter objected to the inclusion of the words 'principles of justice and international law' in the first sentence of article 1 paragraph $1 .{ }^{88}$ The committee on the structure and procedures of the United Nations Charter stated that this did not mean that the Security Council was completely not bound by international law. ${ }^{89}$ These two committee's positions can be reconciled if the Security Council is allowed to deviate from principles of international law, encompassing non-peremptory customary international law, only within certain confines and to adopt measures whose implementation involves a derogation from this law only within certain restraints. ${ }^{90}$ International courts share the same point of view. For the International Tribunal for the Former Yugoslavia, unless the Security Council clearly expresses the opposite, there is a presumption that the Council does not want to disregard customary international law, including customary international human rights law. ${ }^{91}$ According to the European Court of Human Rights, 'there must be a presumption that the Security

of South Africa in Namibia (South West Africa) notwithstanding Security Council Resolution 276 (1970) (n 23) para 22.

87 Evelyne Lagrange, 'Le Conseil de sécurité des Nations Unies peut-il violer le droit international?' (2004) 37 Revue belge de droit international 568, 580.

88 Supra n 82.

89 United Nations Conference on International Organization - Documents (United Nations \& Library of Congress 1945-1955) vol 11 378-380.

90 De Wet (n 83) 186-187.

91 Dusko Tadić, 1999 (n 80) para 296.

(C) Verlag Österreich 
Council does not intend to impose any obligation on member States to breach fundamental principles of human rights', that include customary human rights. ${ }^{92}$

This article will explain below, when and to what extent the Council is allowed to derogate or to ask United Nations Member States to derogate from general international law, especially from general international human rights law, when acting under Chapter VII. There is however an exception to this possible derogation. As will be shown in part III of this paper, the Security Council must respect peremptory international human rights law and cannot require from Member States a deviation from this law.

\section{Application of the Necessity-Proportionality Principle}

\section{The Principle}

Once the Security Council has determined that there is a threat to the peace, a breach of the peace, or an act of aggression, it can recommend or decide what measures are to be taken in order to maintain or restore international peace and security. The enforcement measures adopted by the Security Council are of three kinds: provisional measures, non-military enforcement measures or military enforcement measures (articles 40, 41 and 42 of the United Nations Charter respectively). In accordance with article 40 , the Security Council may '... call upon the parties concerned to comply with such provisional measures as it deems necessary or desirable' (emphasis added). In conformity with article 42 , should the Security Council consider that non-military coercive measures provided for in article 41 '... would be inadequate or have proved to be inadequate' (emphasis added), it may take a forcible action '... as may be necessary to maintain or restore international peace and security' (emphasis added).

The Security Council is not obliged to first adopt recommendations before going on to enforcement measures. It is even not obliged to have recourse first to non-forcible measures before deciding on forcible measures. However, Chapter VII coercive measures must be necessary to counter or remove the threat to, or breach of, the peace, or act of aggression, and must be adapted to this end. In particular, with the 'adequacy' guidance in the implementation of articles 41 and 42, the Charter shows a desire to minimise the effect of enforcement measures without, as much as possible, compromising their effectiveness. There must be a rational link between the means and the end pursued, implying that the end should be achieved by the least restrictive means. This was affirmed in debates of the Security Council. ${ }^{93}$ Similarly, the General Assembly stated that '... [s]anctions should be resorted to only with the utmost caution, when other peaceful options provided by the Charter are inadequate'. ${ }^{94}$ Reference should also be made to the International Court of Justice, which found that action taken by the United Nations, which is '... appropriate for the fulfilment of one of [its] stated purposes' (emphasis added), is presumed to be intra vires. ${ }^{95}$ In conclusion, Chapter VII of the United Nations

92 Al-Jedda (n 70). See also in favour of such a presumption Nabil Sayadi and Patricia Vinck (n 12) 36 (individual opinion of Sir Nigel Rodley (concurring)).

$93 \mathrm{Eg}$ the debate on Security Council sanctions in (2000) UN Doc S/PV 4128.

94 Annex II, GA Res 51/242 (15 September 1997), para 1, UN Doc A/RES/51/242.

95 Certain Expenses of the United Nations (Article 17, Paragraph 2, of the Charter) (n 85) 168. 
Charter indicates that the Security Council is bound by a principle of necessity-proportionality in the implementation of that Chapter. ${ }^{96}$

As explained above, in part II A 2, in accordance with the principle of good faith, the Security Council must respect, as much as possible, human rights guaranteed by the United Nations treaties on human rights in force in two situations. First, it must do so when adopting measures affecting directly individuals. Second, it must do so when taking measures having an impact on individuals indirectly, through their implementation by United Nations Member States without any margin of appreciation - or by a regional organisation to which Member States transferred the implementation of Security Council measures. Furthermore, in conformity with the principle of necessity-proportionality, the Security Council must adapt the scope of its peace enforcement action to what seems to be necessary and proportionate to maintain or re-establish international peace and security. If the latter principle is applied to the obligation of the Security Council to respect in principle human rights in United Nations human rights treaties, it appears that the Council must respect those rights when adopting measures affecting individuals or when asking United Nations Member States to adopt measures having an impact on individuals, unless it is necessary to derogate from those human rights for the success of its coercive peace-keeping action. The scope of the derogation must then be as minimal as possible, and only to the extent required by the objective pursued, namely the maintenance or restoration of international peace and security.

As stated above, in part II B, the Security Council may, in peace enforcement action, derogate from non-peremptory customary international law, including customary international human rights law. It may also impose on United Nations Member States the need to derogate from that law in the enforcement of its mandatory measures. The implementation of the principle of necessity-proportionality inherent in coercive peace-keeping action of the Security Council allows it to ascertain when and to what extent the Council can first, deviate from non-peremptory customary international law, in particular from customary international human rights law, second, can ask Member States to deviate from that law. It is submitted that the Security Council is allowed to do so, only if it is necessary for the success of its measures of peace enforcement and only to the extent required by this aim. Thus, the necessity-proportionality principle should apply to the deviation by the Security Council from human rights whether they are only enshrined in United Nations human rights treaties or also in non-peremptory customary international law. For instance, this principle should be implemented to the departure by the Security Council from the right to a fair trial guaranteed in the ICCPR (article 14) as well as, at least in its core components, in non-peremptory customary international law. ${ }^{97}$ The necessity-proportionality principle also applies when the Security Council requires from

96 Judith G Gardam, 'Legal Restraints on Security Military Enforcement Action' (1995-1996) 17 Mich J. Int'I L. 285, 298; Krisch, 'Introduction to Chapter VII : The General Framework' (n 84) 1260; Antonios Tzanakopoulos, Disobeying the Security Council (OUP 2011) 64-65; Gérard Cahin, 'La notion de pouvoir discrétionnaire appliquée aux organisations internationales' (2003) 107 Revue générale de droit international public 535, 578-579.

97 For the customary nature of the core components of the right to a fair trial - determination of any criminal charge against an individual, or of his/her rights and obligations in a suit at law by an independent and impartial tribunal -, see supra $n$ 75. It is however argued that the most fundamental guarantees of the right to a fair trial when the trial may lead to the death penalty are not only customary, but also peremptory. See infra part III B. 
Member States to depart from human rights in United Nations Human Rights treaties, and for some of those rights, also in non-peremptory customary international law. ${ }^{98}$

'Necessity' concerns whether the objective of the maintenance or restoration of international peace and security warrants a derogation from human rights; 'proportionality' determines the scope of the derogation from human rights that is justified to achieve the goal. The United Nations, acting through the Security Council, has at its disposal a legal 'opt-out' regime, similar to legal emergency regimes that exist in most domestic legal orders. ${ }^{99}$ It can 'contract out' of human rights guaranteed in United Nations human rights treaties, and, for some of those rights, also in non-peremptory customary international law. It can also require Member States that they depart from those rights in the implementation of its measures. It can do so in an emergency, that of a threat to the peace, breach of the peace or act of aggression and only if it is necessary to react to that emergency.

In conclusion, the Security Council is bound by an obligation to observe human rights enshrined in United Nations human rights treaties and, for some of those rights, in non-peremptory customary international law. It is also bound by an obligation not to adopt measures whose implementation by United Nations Member States necessitates that they disregard those human rights. The same prohibition applies in the situation when Member States transferred the implementation of Security Council measures to a regional organisation, such as the European Union. The Security Council can depart from the two obligations referred to above, only if it is necessary for and proportionate to its aim of the maintenance or re-establishment of international peace and security. Therefore, it is here argued that the Security Council is only bound by derogable obligations of direct and indirect respect for those human rights guaranteed in United Nations human rights treaties and, concerning some of those rights, in non-peremptory customary international law.

\section{Its Application}

The United Nations Charter gives to the Security Council a broad margin of appreciation with respect to the necessity and proportionality of its coercive action. ${ }^{100}$ Article 40 refers to provisional measures that the Security Council 'deems' appropriate whereas article 42 allows for military action should the Council 'consider' that measures under article 41 were inadequate or would be inadequate. As correctly stated by the International Tribunal for the Former Yugoslavia, '... the Security Council has a very wide margin of discretion under article 39 to choose the appropriate course of action and to evaluate the suitability of the measures chosen, as well as their potential contribution to

98 Fassbender, 'Sources of human rights obligations binding the UN Security Council' (n 25) 91 (applying the principle of necessity-proportionality to the impact on human rights by Security Council measures).

99 Simon Chesterman, 'UNaccountable? The United Nations, Emergency Powers, and the Rule of Law' (2009) 42 Vand J Transnat'I L 1509, 1512; Georges Abi-Saab, 'The Security Council Legibus Solutus? On the Legislative Forays of the Council' in Laurence Boisson de Chazournes and Marcelo Kohen (eds), International Law and the Quest for its Implementation (Brill 2010) 23, 29; Devon Whittle, 'The Limits of Legality and the United Nations Security Council: Applying the Extra-Legal Measures Model to Chapter VII Action' (2015) 26 EJIL 671, 679-680.

100 Krisch, 'Introduction to Chapter VII: The General Framework' (n 84) 1260; Tzanakopoulos (n 96) 66. 
the restoration or maintenance of peace'. ${ }^{101}$ If this statement is applied to the observance of human rights by the Security Council, it is here argued that the Council has a significant degree of discretion in assessing whether and to what extent it is necessary for the success of its enforcement action to derogate from human rights guaranteed in United Nations human rights treaties. The same applies for some of those rights that are also guaranteed in non-peremptory customary international law. It is also argued that the Council has a similar degree of discretion in deciding whether and to what extent it can require from Member States a derogation from human rights, whether those rights are only enshrined in United Nations human rights treaties or also in non-peremptory customary international law.

The broad margin of appreciation the Security Council enjoys in determining whether a derogation from human rights is necessary and proportional to the aim pursued is confirmed by the practice of the Council and of its sanctions committees, in the adoption of humanitarian exemptions to enforcement measures. This practice is very diverse from one sanctions regime to another. ${ }^{102}$ Such heterogeneity can even be found within a sole sanctions regime. A sanctions committee may refuse a humanitarian derogation that it however allowed in another apparently similar case. ${ }^{103}$ It is to be noted that the lack of transparency in the activity of the Security Council and of its sanctions committees makes it difficult to determine common legal requirements in the attribution of humanitarian exemptions. ${ }^{104}$ The Security Council and its sanctions committees make assessment on a case by case basis, with an important degree of discretion, on how to respect human rights in the Council Chapter VII action. ${ }^{105}$

Thus, coercive measures of the Security Council should be unlawful only if their impact on human rights embodied in United Nations human rights treaties in force is manifestly not necessary for the success of its peace enforcement action and/or out of all proportion to this purpose. The same applies as regard some of those rights that are also guaranteed in non-peremptory customary international law. Similarly, mandatory measures of the Security Council should be unlawful when they impose on Member States an impact on those human rights contained in United Nations human rights treaties in force, where it is manifestly not necessary for the maintenance or restoration of world peace and/or totally in disproportion to this aim. Again, the same applies for some of those rights that are also in non-peremptory customary international law. Along similar lines, the International Tribunal for the Former Yugoslavia recognised that the power to review Security Council action exists in the case of a 'manifest contradiction with the Principles and Purposes of the Charter' (emphasis added). ${ }^{106}$

101 Dusko Tadić, 1995 (n 20) para 32.

102 On the application of exemptions to enforcement measures by Security Council sanctions committees, Gian Luca Burci, 'Interpreting the Humanitarian Exceptions through the Sanctions Committees' in Vera Gowlland-Debbas (ed), United Nations Sanctions and International Law (Kluwer Law International 2001) 143-154; Conlon (n 58) 249-284; François Alabrune, 'La pratique des comités de sanctions du Conseil de sécurité depuis 1990' (1999) 45 Annuaire français de droit international 226, 239-249.

103 Burci (n 102) 145 note 3.

104 Kolliopoulos (n 58) 583; Dorothee Starck, Die Rechtmäßigkeit von UNO-Wirtschaftssanktionen in Anbetracht ihrer Auswirkungen auf die Zivilbevölkerung (Duncker \& Humblot 2000) 136-137.

105 Burci (n 102) 145.

106 Dusko Tadić, 1995 (n 20) para 21.

(c) Verlag Österreich 
The necessity-proportionality principle also justifies derogations by States from most of the human rights guaranteed by the ICCPR. In accordance with article 4 paragraph 1 of the Covenant: '...$[i] n$ time of public emergency which threatens the life of the nation and the existence of which is officially proclaimed, the States Parties to the present Covenant may take measures derogating from their obligations under the present Covenant to the extent strictly required by the exigencies of the situation'. ${ }^{107}$ For the United Nations Human Rights Committee, a public emergency could be '... a natural catastrophe, a mass demonstration including instances of violence, or a major industrial accident $^{\prime 108}$ as well as an international armed conflict or a violent internal unrest. ${ }^{109}$ Article 4 paragraph 1 of the ICCPR is similar to article 15 paragraph 1 of the European Convention on Human Rights. ${ }^{110}$ The organs monitoring the Convention have given more precise criteria than the Human Rights Committee to determine a state of emergency, which may be drawn upon for the interpretation of article 4 of the Covenant. For the European Commission of Human Rights, a public emergency must be actual or imminent; its effects must affect the whole nation; it must threaten the continuance of the organised life of the community; it must relate to an exceptional crisis or danger. ${ }^{111}$ It is argued that the concept of 'public emergency' is similar to the concepts of 'threat to the peace', 'breach of the peace', or 'act of aggression' of Chapter VII of the United Nations Charter. ${ }^{112}$ All concepts suppose the existence of a crisis that is actual or imminent, that affects a community - a national community or the international community of States and that threatens the functioning of that community. ${ }^{113}$ Furthermore, like a public emergency in a State, a threat to the peace, breach of the peace, or act of aggression, is officially proclaimed at the international level by the United Nations Security Council.

The question then arises whether article 4 paragraph 1 of the Covenant could be applied by analogy to Chapter VII action in order to justify the deviation from international human rights in the implementation of Security Council measures. In conformity with the Covenant, the scope of the derogations from human rights is strictly necessary

107 ICCPR art 4, para 1 (n 4) 174. A derogation from art 6, 7, 8, 11, 15, 16 and 18 ICCPR is however inadmissible in accordance with art 4 para 2 . In addition to their derogation, many human rights provide themselves for their limitations. In the ICCPR, a number of articles refer to limiting human rights if it is provided by law and necessary in order to protect national security, public order, public health, morals, the rights and freedoms of others, or public safety.

108 UNHRC 'General Comment 29 States of Emergency (Article 4)' (2001) UN Doc CCPR/C/21/Rev 1/ Add.11 para 3.

109 As recognised in the doctrine of the Committee in reviewing States' reports and in the proceedings under the First Optional Protocol: Manfred Nowak, UN Covenant on Civil and Political Rights (NP Engel 2005) 89-90.

110 Convention for the Protection of Human Rights and Fundamental Freedoms (European Convention on Human Rights, as amended) (ECHR) art 15, para 1.

111 Denmark, Norway, Sweden and the Netherlands v Greece App no 3321/67, no 3322/67, no 3323/67, no 3344/67 (5 November 1969) 12 EHRR 83 para 113. See also Ireland $v$ The United Kingdom App no 5310/71 (ECtHR, 18 January 1978) paras 205-224.

112 For a definition of the concepts, Nico Krisch, 'Article 39' in Bruno Simma et al (eds), The Charter of the United Nations ( $3^{\text {rd }}$ edn, OUP 2012) vol II 1272, 1278-1294

113 Scott Sheeran \& Catherine Bevilacqua, 'The UN Security Council and international human rights obligations' in Scott Sheeran \& Nigel S Rodley (eds), Routledge Handbook of International Human Rights Law (Routledge 2013) 371, 399. Also Gerhard Thallinger, 'Sense and Sensibility of the Human Rights Obligations of the United Nations Security Council' (2007) 67 Zeitschrift für ausländisches öffentliches Recht und Völkerrecht 1015, 1029. 
and proportionate to address the public emergency. ${ }^{114}$ Such a qualified necessity-proportionality requirement could not be analogously implemented to United Nations Chapter VII action. Indeed, as was shown previously, a more lenient, ordinary, necessity-proportionality principle applies to the Security Council in its choice of appropriate action to address a threat to the peace, breach of the peace, or act of aggression, in particular in its decision on whether and how to deviate from international human rights. ${ }^{115}$ However, the Security Council should use the interpretation of human rights derogations from the Covenant by States and the Human Rights Committee as guidance in the balance it makes between the maintenance of international peace and security and the protection of human rights. The requirements of necessity and proportionality, justifying a derogation from the ICCPR, should inform the content and scope of the necessity-proportionality principle, justifying a derogation from international human rights in the implementation of Security Council Chapter VII measures. ${ }^{116}$

The legal standard governing the obligation of the Security Council to respect human rights when implementing coercive measures or when imposing the implementation of coercive measures to Member States, must be applied to the circumstances of each situation. The threshold for derogations from human rights cannot be abstract but needs to be assessed contextually. First of all, the Security Council must establish which human rights exactly could be affected by an act it aims to adopt, whether the act is implemented by the Council itself or by Member States, without any margin of appreciation - or sometimes by a regional organisation to which Member States transferred the implementation of Security Council action. Then, the Security Council should balance the objective of securing international peace and security with the objective of protecting the relevant human rights to the greatest possible extent in the particular case. A derogation from human rights of a particular group of persons in the implementation of a Security Council measure must be necessary and proportionate to the objective the measure is meant to reach at a given moment. The requirements of necessity and proportionality must be applied to the geographical and material scope as well as to the duration of the human rights derogation. Thus, the Security Council should assess whether its sanctions target the proper individuals. The Security Council should ensure that its sanctions do not affect human rights of those individuals in an unnecessary and unproportioned way. Finally, the Security Council should adopt sanctions only as long as that appears necessary. Sanctions that continue for a long period of time and that are without effects in securing world order may become unlawful. ${ }^{117}$ In assessing the necessity and proportio-

114 'General Comment 29, States of Emergency (Article 4)' (n 108) para 4; Jaime Oraa, Human Rights in States of Emergency in International Law (Clarendon Press 1992) 152-159. The strict necessityproportionality principle is not temporised by the Human Rights Committee that is reluctant to grant States parties a margin of appreciation in the implementation of art 4 of the Covenant. Dominic McGoldrick, 'The Interface between Public Emergency Powers and International Law' (2004) 2 International Journal of Constitutional Law 380, 400.

115 Erika de Wet, 'The Role of Human Rights in Limiting the Enforcement Power of the Security Council: A Principled View' in Erika de Wet \& André Nollkaemper (eds), Review of the Security Council by Member States (Intersentia 2003) 7, 18.

116 Christopher Michaelsen, 'Human Rights as Limits for the Security Council: A Matter of Substantive Law or Defining the Application of Proportionality?' (2014) 19 Journal of Conflict \& Security Law 451, 468.

117 Working paper prepared by Marc Bossuyt for the Sub-Commission on the Promotion and Protection of Human Rights, The Adverse Consequences of Economic Sanctions, E/CN 4/Sub 2/2000/33, paras 43-45. 
nality of the human rights implications of its measures for the aim of maintaining or restoring international peace and security, the Security Council should enjoy a broad margin of appreciation.

The legal standards of necessity and proportionality have been applied by European Courts to States or a regional organisation, when they implemented Security Council action, with no margin of appreciation. It is here submitted that similar standards should be applied to the Security Council itself, when it imposes on Member States the enforcement of its action, without any leeway for discretion. The Courts of the European Union and the European Court of Human Rights balanced the objective of international peace and security pursued by the implementation without any latitude of Security Council resolutions, with respect for human rights by States or a regional organisation. In Bosphorus $v$ Minister for Transport, Energy and Communication and others, the applicant, Bosphorus Airways, complained that a European Community Regulation giving effect in the then Community legal order to a Security Council resolution deciding a trade embargo on the Federal Republic of Yugoslavia (Serbia and Montenegro), infringed its fundamental rights, such as its right to peaceful enjoyment of its property and freedom to contract a commercial activity. Indeed, an aircraft belonging to Bosphorus Airways was impounded by an Irish ministerial order under the European Community Regulation. The European Court of Justice decided that the embargo imposed by the Security Council resolution was to apply to the aircraft. The Court noted that the objective of fundamental importance to the international community, which was to re-establish peace and security in Bosnia-Herzegovina, supervened over the rights of Bosphorus. It then ruled that the impounding of the aircraft was neither inappropriate nor disproportionate. ${ }^{118}$

In the first Kadi and Yusuf cases, the applicants, individuals listed on the then Al-Qaida and Taliban sanctions list, complained that a European Community Regulation implementing a Security Council resolution infringed several of their rights, in particular their right to respect for property guaranteed under the then European Community Law. ${ }^{119}$ Indeed, their funds were frozen by the contested regulation. The European Court of First Instance established that the Security Council sanctions decided against the listed individuals pursued a fundamental public interest for the international community, namely the fight against threats to international peace and security caused by terrorist acts. Taking this objective into consideration, the Court decided that the freezing of funds did not constitute '... an arbitrary, inappropriate or disproportionate interference' (emphasis added) with the right to property. ${ }^{120}$ The most recent Kadi case concerned an appeal against a judgment of the General Court (previously the European Court of First Instance) that had annulled a new European Community Regulation maintaining the listing of Mr Kadi on the sanctions list. ${ }^{121}$ The appellants challenged both the standard of review applied by the General Court, and the way it dealt with the substantive claims by Mr Kadi (violation of the rights of the defence, the right to effective judicial protection,

118 Case C-84/95 Bosphorus Hava Yollari Turizm ve Ticaret AS v Minister for Transport, Energy and Communications and Others [1996] ECR I-3978 para 26.

119 Yassin Abdullah Kadi v Council of the European Union and Commission of the European Communities (n 15); Ahmed Ali Yusuf and Al Barakaat International Foundation (n 16).

120 Yassin Abdullah Kadi $v$ Council of the European Union and Commission of the European Communities (n 15) para 251; Ahmed Ali Yusuf and Al Barakaat International Foundation (n 16) para 302. See also Chafiq Ayadi (n 16) para 125; Faraj Hassan (n 16) para 101.

121 Yassin Abdullah Kadi v European Commission (n 15). 
and the principle of proportionality as it relates to the protection of property as protected by European Union Law). The European Court of Justice admitted that considerations to do with international security may preclude the disclosure of some information concerning the listing or the maintenance of the listing of a person on the then Al-Qaida sanctions list and thus the impact on his/her procedural rights. ${ }^{122}$ For the Court, '... it is necessary to strike an appropriate balance between the requirements attached to the right to effective judicial protection ... and those flowing from the security of the European Union or its Member States or the conduct of their international relations' (emphasis added). ${ }^{123}$ In that case, the Court decided that the non-disclosure of evidence by European Union institutions that they did not have themselves did not violate Mr Kadi's fundamental rights. ${ }^{124}$

In the first Al-Dulimi case, Mr Dulimi, listed by the 1483 Sanctions Committee, complained before the European Court of Human Rights that Switzerland had infringed several of his rights guaranteed under the European Convention on Human Rights. Mr Dulimi argued in particular that his right to a fair trial had been violated following the Swiss courts' refusal to adjudicate on the substance on a case he brought to the courts complaining that his assets had been frozen by the Swiss authorities. The confiscation of his assets was the result of the implementation, by Switzerland, of Security Council resolution 1483. The European Court of Human Rights acknowledged that the right to a fair trial could be limited under two conditions: there must be a legitimate aim and the limitation must be proportionate to that aim. ${ }^{125}$ The aim, namely the maintenance of international peace and security, was recognised as legitimate. ${ }^{126}$ The Court however, found that the denial by Switzerland of any judicial review was completely disproportionate to reach that objective. For the Court, the very essence of the right of access to a tribunal was impaired. ${ }^{127}$

The requirements of necessity and proportionality should also apply to action by the Security Council that is not enforced by Member States, but by the Council itself. Those requirements should in particular determine the lawfulness of the Security Council listing measures on diverse sanctions lists. There is no independent and impartial tribunal that reviews the listing or de-listing of individuals sanctioned by the Security Council. ${ }^{128}$ Concerning more particularly the ISIL (Da'esh) and Al-Qaida sanctions list, an Ombudsperson, independent and impartial, examines requests from individuals and entities seeking to be removed from the list. However, the recommendations for de-listing of the ombudsperson can be overturned by the Sanctions Committee 1267, a subsidiary organ of the

122 European Commission, Council of the European Union, United Kingdom of Great Britain and Northern Ireland $v$ Yassin Abdullah Kadi (n 15) para 125.

123 Ibid para 128.

124 Ibid paras 138-139.

125 Al-Dulimi and Montana Management Inc (n 15) para 124.

126 Ibid para 127.

127 Ibid para 134. The Al-Dulimi case was referred to the Grand Chamber that arrived at the same conclusion that the Chamber did but with different legal reasoning. For the Grand Chamber, Switzerland had a margin of appreciation in the implementation of Resolution 1483 - a position with which the present author disagrees - so that it could allow, and should have allowed, Al-Dulimi access to a court as required under art 6 para 1 of the European Convention on Human Rights. Al-Dulimi and Montana Management Inc v Switzerland App no 5809/08 (ECtHR, 21 June 2016) paras 146 and 151.

128 Lists of the sanctions committees and de-listing procedures available at <https://www.un.org/sc/ suborg/en/sanctions/information> accessed 14 June 2016. 
Security Council. Thus, the institution of the ombudsperson does not bring the ISIL (Da'esh) and Al-Qaida sanctions regime into compliance with the international right to a fair trial. ${ }^{129}$ This right is guaranteed by the ICCPR and - at least in its core components - in non-peremptory customary international law. ${ }^{130}$ Following the reasoning above, the United Nations Security Council could derogate from the international right to a fair trial if it where necessary to the maintenance or restoration of international peace and security, and the extent of the derogation should be proportionate to that aim. However, in the opinion of this author, a complete derogation from the right to access to a judge is obviously not necessary to the pursued objective. Indeed, the institution of an international tribunal reviewing the listing or de-listing of persons targeted by the Security Council would not impair the aim of the Council in maintaining or restoring international peace and security. The tribunal could only review the criteria required for the listing, for instance, as regards the ISIL (Da'esh) and Al-Qaida sanctions regime, the connection of the relevant individual with ISIL (Da'esh) or the Al-Qaida organisation, once the individual is already listed and therefore sanctioned. ${ }^{131}$ The efficacy of the sanctions regimes against individuals would not be jeopardised by the establishment of a tribunal reviewing whether the listing is well-grounded. ${ }^{132}$ It is thus argued here that the derogation from the right to a fair trial by the Security Council when it lists individuals is obviously not necessary for the fulfilment of its coercive peace-keeping action and that the Council therefore infringes that right.

\section{An Absolute Obligation of the Security Council to Respect Human Rights Contained in Peremptory International Law}

\section{A. The Obligation}

As stated in part II B of that article, the Security Council may derogate from nonperemptory customary international law relevant to its action. The question is now raised whether this possibility also concerns customary international law that is peremptory. In conformity with article 53 of the Vienna Convention on the Law of Treaties, that codifies that law, a treaty is void if, at the time of its conclusion, it conflicts with a peremptory norm of international law. ${ }^{133}$ Such a norm, also referred to as jus cogens, is a norm from

129 GA, Report submitted to the GA by the Special Rapporteur on the promotion and protection of human rights and fundamental freedoms while countering terrorism (26 September 2012), paras 2735, UN Doc A/67/396. See also European Commission, Council of the European Union, United Kingdom of Great Britain and Northern Ireland $v$ Yassin Abdullah Kadi (n 15) para 133.

130 Supra n 75.

131 Concerning the establishment of a tribunal to review the listing on the ISIL (Da'esh) and Al-Qaida sanctions list: Report submitted to the GA by the Special Rapporteur on the promotion and protection of human rights and fundamental freedoms while countering terrorism (n 129) para 23 ('there is no sustainable vires objection to the establishment of a mechanism of independent judicial review'). Also Irène Couzigou, 'La lutte du Conseil de sécurité contre le terrorisme international et les droits de l'homme' (2008) 1 Revue générale de droit international public 49, 81-83.

132 As stated by the European Court of First Instance: 'A measure freezing funds must, by its very nature, be able to take advantage of a surprise effect and to be applied with immediate effect.' Ahmed Ali Yusuf and Al Barakaat International Foundation (n 16) para 308.

133 Vienna Convention on the Law of Treaties (n 42) 344. 
which no derogation is possible under any circumstance. ${ }^{134}$ It is unlikely that article 53 codified a customary international norm that existed in June 1945 when the United Nations Charter was concluded. Furthermore, in accordance with article 64 of the Vienna Convention on the Law of Treaties, a treaty becomes void if it is in conflict with a new peremptory norm of international law. ${ }^{135}$ Under article 4 of the Vienna Convention, that Convention '.... applies only to treaties which are concluded by States after the entry into force of the present Convention with regard to such States ${ }^{\prime 136}$ - that entry into force occurred on $27^{\text {th }}$ January 1980. The International Law Commission seems however to put aside article 4 of the Vienna Convention on the Law of Treaties as regards the rule embodied in article 64 of the same Convention. Indeed, the Commission considers that article 64 applies to former treaties as well as to existing treaties. It refers to '... former treaties regulating the slave trade, the performance of which later ceased to be compatible with international law owing to the general recognition of the total illegality of all forms of slavery' (emphasis added). ${ }^{137}$ Article 64 applies therefore to the United Nations Charter if it codifies customary international law.

Such was not the case in 1969 when the Vienna Convention on the Law of Treaties was concluded. ${ }^{138}$ Indeed, the inclusion of the concept of peremptory norms of international law in the Vienna Convention on the Law of Treaties encountered many difficulties. ${ }^{139}$ Since then a large number of States agreed with most of the provisions of the Vienna Convention and ratified it or acceded to it. ${ }^{140}$ Furthermore State representatives as well as international courts and arbitral tribunals or other monitoring organs often referred to or applied the notion of jus cogens. ${ }^{141}$ The International Court of Justice referred to it for the first time in 2006. ${ }^{142}$ A majority of academics recognise the existence of peremptory international norms and even consider that they do not only apply to treaties. ${ }^{143}$ The identification of jus cogens norms remains highly controversial. ${ }^{144}$ However, given the frequent and clear references to the concept of jus cogens, in the practice as well as in the literature, it is here argued that there are peremptory norms of international law and that the rule in article 64 of the Vienna Convention on the Law of Treaties

134 Ibid.

135 Ibid 347.

136 Ibid 334.

137 ILC Rep (19 July 1966) 89 UN Doc A/6309/Rev 1.

138 Wladyslaw Czaplinski, 'Jus Cogens and the Law of Treaties' in Christian Tomuschat \& Jean-Marc Thouvenin (eds), The Fundamental Rules of the International Legal Order (Nijhoff 2006) 83, 86.

139 The International Law Commission (ILC) considered itself that '[t]he emergence of rules having the character of jus cogens is comparatively recent'. ILC Rep (19 July 1966) 76 UN Doc A/6309/Rev 1.

140114 States are party to the Convention in June 2016.

141 Antonio Cassese, International Law (2 ${ }^{\text {nd }}$ edn, OUP 2005) 202-203; Paul Tavernier, 'L'identification des règles fondamentales, un problème résolu? Jus cogens and obligation erga omnes' in Christian Tomuschat \& Jean-Marc Thouvenin (eds), The Fundamental Rules of the International Legal Order (Nijhoff 2006) 1, 5-12.

142 Case Concerning Armed Activities on the Territory of the Congo (New Application: 2002) (Democratic Republic of the Congo $v$ Rwanda) (merits) [2006] IC] Rep 6, 33 and 52.

143 See the references quoted in Robert Kolb, Théorie du jus cogens international (Presses Universitaires de France 2001) 379-386.

144 The prohibition on the use of armed force between States, the prohibition to torture, the prohibition of genocide, and the prohibition of slavery are commonly seen in academia as jus cogens norms. For an attempt to identify jus cogens norms, see for instance Lauri Hannikainen, Peremptory Norms (Jus Cogens) in International Law (Lakimiesliiton Kustannus 1988) 315-727; Alexander Orakhelashvili, Peremptory Norms in International Law (OUP 2006) 50-66. 
has become part of customary international law. ${ }^{145}$ The provision of article 64 of the Vienna Convention on the Law of Treaties thus applies to the United Nations Charter. In this author's view, applying the content of article 64 to the United Nations Charter prohibits interpretation of the Charter so as to allow United Nations organs, in particular the Security Council, to deviate from jus cogens norms.

In current international law, there is another, more simple, way to demonstrate that the United Nations, and thus also its organs, is bound by jus cogens norms, other than the one that resorts to the application of the Vienna Convention on the Law of Treaties. Peremptory norms of international law contain essential values for the international community of States. ${ }^{146}$ Today, subjects of international law, both States and international organisations, must not derogate from norms of jus cogens, either in a treaty or in a (non-peremptory) customary international norm ${ }^{147}$ or a unilateral act. ${ }^{148}$ Otherwise the concept of jus cogens would not make any sense. In accordance with the statement of the International Law Commission as early as 1966, '... a rule of jus cogens is an overriding rule depriving any act or situation which is in conflict with it of legality'. ${ }^{149}$

Therefore, it is here submitted that resolutions of the Security Council, even if adopted on the basis of Chapter VII of the United Nations Charter, have to be in conformity with peremptory norms of international law, including with peremptory human rights law. This conclusion is shared by international, regional and domestic courts ${ }^{150}$ as well as by a majority of academics, including by those who consider that the Security Council is free to derogate from (non-peremptory) customary international law. ${ }^{151}$ The Draft Arti-

145 Cassese (n 141) 204; Andreas L Paulus, 'Jus Cogens in a Time of Hegemony and Fragmentation' (2005) 74 Nord J Int/ L 297, 330.

146 During the UN conference on the law of treaties, several State delegations emphasized the importance of jus cogens norms for the existence of the international community of States. UN Conference on the Law of Treaties, First session 26 March-24 May 1968, Summary records of the plenary meetings, UN Doc A/Conf 39/11. Mexico, 52 ${ }^{\text {th }}$ meeting, 4 May 1968, para 7; Iraq, ibid, para 23; Lebanon, ibid, para 42; Uruguay, 53 ${ }^{\text {th }}$ meeting, 6 May 1968, para 48; Romania, 54 ${ }^{\text {th }}$ meeting, 6 May 1968, para 55; Czechoslovakia, 55 $5^{\text {th }}$ meeting, 7 May 1968, para 25.

147 Since a peremptory norm of general international law is a norm accepted by the international community of States from which no derogation is permitted, it must be a customary norm. Indeed, a customary norm is 'evidence of a general practice accepted as law' by the international community of States, in conformity with art 38 of the ICJ Statute.

148 Orakhelashvili (n 144) 206-216; Eric Suy, 'The Concept of Jus Cogens in Public International Law' in Carnegie Endowment for International Peace/European Centre (ed), The Concept of Jus Cogens in International Law (Carnegie Endowment for International Peace 1967) 17, 75; Linos-Alexandre Sicilianos, Les réactions décentralisées à l'illicite (Librairie générale de droit et de jurisprudence 1990) 340-344.

149 ILC Rep (19 July 1966) 89 UN Doc A/6309/Rev 1. See also Joint dissenting opinion of Judges Rozakis and Caflisch joined by Judges Wildhaber, Costa, Cabral Barreto and Vajić, para 1. ('By accepting that the rule on prohibition of torture is a rule of jus cogens, the majority recognise that it is hierarchically higher than any other rule of international law, be it general or particular, customary or conventional, with the exception, of course, of other jus cogens norms. For the basic characteristic of a jus cogens rule is that, as a source of law in the now vertical international legal system, it overrides any other rule which does not have the same status.') Al-Adsani $v$ The United Kingdom App no 35763/97 (ECtHR, 21 November 2001) para 1.

150 Dusko Tadić, 1995 (n 20) para 28; Dusko Tadić, 1999 (n 80) para 296; Ahmed Ali Yusuf and Al Barakaat International Foundation (n 16) para 277; Yassin Abdullah Kadi $v$ Council of the European Union and Commision of the European Communities ( $n$ 15) para 226; Chafiq Ayadi (n 16) para 116; Faraj Hassan (n 16) para 92; Youssef Nada v SECO, Swiss Federal Supreme Court, 14 November 2007, 133 Entscheidungen des Schweizerischen Bundesgerichts II para 7.

151 Matthias J Herdegen, 'The 'Constitutionalization' of the UN Security System' (1994) 27 Vand J Transnat'I L 135, 156; Krisch, 'Introduction to Chapter VII. The General Framework' (n 85) 
cles on the Responsibility of International Organizations in particular, assume that any act of international organisations, thus including acts of the United Nations Security Council, must respect jus cogens. ${ }^{152}$

The obligation of the Security Council to conform to jus cogens is linked to the obligation of the Council not to require from United Nations Member States a derogation from jus cogens, including jus cogens human rights. ${ }^{153}$ Article 1 paragraph 1 of the United Nations Charter cannot be interpreted so as to allow the Security Council to take binding measures whose implementation by Member States involves deviation from peremptory international law. The same applies when Member States transferred the implementation of Security Council action to a regional organisation, such as the European Union. Several regional and domestic courts have recognised that the Security Council must observe peremptory human rights law when adopting enforcement action to be implemented by Member States or a regional organisation, without any margin of discretion. ${ }^{154}$ In the same vein, academia widely accepts that a measure implementing a Security Council resolution does not prevail over a peremptory norm, including a peremptory human rights norm, in case of an inconsistency between the two provisions. ${ }^{155}$ As Judge Hersch Lauterpacht stated in his Separate Opinion in the Genocide case: '... [t] he relief which Article 103 of the Charter may give the Security Council in case of conflict between one of its decisions and an operative treaty obligation cannot ... extend to a conflict between a Security Council resolution and jus cogens'. ${ }^{156}$ Furthermore, reference can be made to article 15 of the Draft Articles on the Responsibility of International Organizations. ${ }^{157}$ In accordance with that provision, the United Nations would engage its responsibility if it took coercive measures whose enforcement necessitated a violation by Member States of peremptory international law, including peremptory human rights law.

\section{B. Its Application}

Which international human rights belong to the category of jus cogens is controversial. But the ICCPR, the European Convention on Human Rights, and the American Convention on Human Rights recognise that certain rights cannot be derogated from by

1259-1260; Gabriel H Oosthuizen, 'Playing the Devil's Advocate: the United Nations Security Council is Unbound by Law' (1999) 12 LIL 549, 559; David Schweigman, The Authority of the Security Council under Chapter VII of the UN Charter (Kluwer Law International 2001) 197; Alain Pellet, 'Rapport introductif: peut-on et doit-on contrôler les actions du Conseil de sécurité?' in Société française de droit international (ed), Chapitre VII de la Charte des Nations Unies: actes du XXVIIIe colloque de Rennes, 2 au 4 juin 1994 (A Pedone 1995) 221, 237; Christian Dominicé, 'Le Conseil de sécurité et le droit international' in Jeanne Belhumeur \& Luigi Condorelli (eds), L'ordre juridique international entre tradition et innovation (Presses Universitaires de France 1997) 207, 218.

152 Art 26 and 41 Draft Articles on the Responsibility of International Organizations (n 16).

153 In that sense Alexander Orakhelashvili, 'The Impact of Peremptory Norms on the Interpretation and Application of United Nations Security Council Resolutions' (2005) 16 EJIL 59, 77.

154 Ahmed Ali Yusuf and Al Barakaat International Foundation (n 16) para 282; Yassin Abdullah Kadi v Council of the European Union and Commision of the European Communities (n 15) para 231; Chafiq Ayadi (n 16) para 116; Faraj Hassan (n 16) para 92; Youssef Nada (n 150).

155 Report of the study group of the International Law Commission (ILC) (prepared by Martti Koskenniemi) (n 40) para 346 with further references.

156 Application of the Convention on the Prevention and Punishment of the Crime of Genocide (Bosnia Herzegovina v Serbia and Montenegro), separate opinion of Judge Lauterpacht (n 23) para 100.

157 Supra n 36. 
States parties even in a state of emergency. ${ }^{158}$ Similarly, in the international legal order, peremptory human rights norms cannot be derogated from in any international act. Thus, the fact that certain human rights cannot be deviated from by the numerous States parties to the three human rights treaties referred to above may constitute a sign in favour of their peremptory international nature. ${ }^{159}$ The ICCPR has been ratified by almost all States in the world; ${ }^{160}$ all States members of the Council of Europe are party to the European Convention on Human Rights; ${ }^{161}$ a majority of the States members of the Organization of American States are party to the American Convention on Human Rights. ${ }^{162}$ These three general human rights treaties have four non-derogable rights in common. Article 4 paragraph 2 of the ICCPR, article 15 paragraph 2 of the European Convention on Human Rights, and article 27 paragraph 2 of the American Convention on Human Rights, do not allow any derogation to: the right to life, the right not to be tortured or to be subjected to cruel, inhuman or degrading treatment, the right not to be held in slavery or in servitude, and the right not to be punished without law. ${ }^{163}$ Furthermore, in accordance with article 3 common to the 1949 Geneva Conventions, the right to life as well as the right not to be tortured or to be subjected to cruel or degrading treatment must be guaranteed even in armed conflicts, that constitute a category of a state of emergency. ${ }^{164}$ The Geneva Conventions have been ratified by all United Nations Member States. Thus, considering the number of States that have recognised the non-derogability of the right to life and of the right not to be tortured or subjected to cruel, inhuman or degrading treatment in human rights treaties and in the Geneva Conventions, it is here submitted that these rights have a peremptory nature under general international law. ${ }^{165}$ The prohibition on torture and the prohibition on inhuman and degrading treatment have already been recognised as jus cogens norms by international jurisdictions. ${ }^{166}$

158 ICCPR art 4, para 2 (n 4) 174; Convention for the Protection of Human Rights and Fundamental Freedoms art 15, para 2 (n 110); American Convention on Human Rights (adopted 22 November 1969, entered into force 18 July 1978) art 27, para 21144 UNTS 152.

159 'General Comment 29, States of Emergency (Article 4)' (n 108) para 11. See also Stefan Oeter, 'Ius cogens und der Schutz der Menschenrechte' in Stephan Breitenmoser, Berhnhard Ehrenzeller, Marco Sassoli, Walter Stoffel, Beatrice Wagner Pfeifer (eds), Human Rights, Democracy and the Rule of Law (Dike 2007) 499, 509.

160168 States in June 2016.

16147 States in June 2016.

16223 among 35 States in June 2016.

163 Supra n 158.

$164 \mathrm{Eg}$ Convention for the Amelioration of the Condition of the Wounded and Sick in Armed Forces in the Field (adopted 12 August 1949, entered into force 21 October 1950) art 3, para 175 UNTS 32 and 34.

165 Frédéric Sudre, Droit européen et international des droits de l'homme (PUF 2015) 197 no 127.

166 For the prohibition to torture: Prosecutor v Anto Furundzija (Judgment) ICTY-95-17/1 (10 December 1998) para 144; Al-Adsani (n 149) 101; Questions Relating to the Obligation to Prosecute or Extradite (Belgium v Senegal) (merits) [2012] IC] Rep 422, 457.

For the prohibition to inhuman and degrading treatment: Caesar $v$ Trinidad and Tobago (11 March 2005) Inter-American Court of Human Rights Series C no 123 para 100; Ahmed Ali Yusuf and Al Barakaat International Foundation (n 16) para 291; Yassin Abdallah Kadi $v$ Council of the European Union and Commision of the European Communities ( $n$ 15) para 240. Examing whether sanctions applied to the individuals listed on the list of the Sanctions Committee 1267 are contrary to a jus cogens norm, the European Court of First Instance stated in these two judgments that the '... express provision of possible exemptions and derogations thus attaching to the freezing of the funds of the persons in the Sanctions Committee's list clearly shows that it is neither the purpose nor the effect of that measure to submit those persons to inhuman or degrading treatment'. 
The right to life knows of exceptions. ${ }^{167}$ One exception concerns in particular the death penalty, providing it is imposed in accordance with the law in force at the time of the commission of the crime and pursuant to a judgment. ${ }^{168}$ Procedural guarantees secure the protection of the right to life. Indeed, the non-punishment without law and the right to a fair trial guarantee a fair imposition of the death penalty and thus protect the right to life. ${ }^{169}$ The right not to be punished by the death penalty without law and the right to a fair trial when the death penalty may be imposed are accessory rights to the right to life. Thus, since this latter right cannot be derogated from under general international law, the right not to be punished to a sentence of death without law should itself be nonderogable. Similarly, the right to a fair trial, at least in its core content - determination of any criminal charge against an individual by an independent and impartial tribunal should be non-derogable, when applied in a process in which the sentence of death may be pronounced. ${ }^{170}$ Otherwise the intangibility of the right not to be arbitrarily deprived of his life could be circumvented. Thus, it is argued that the right not to be punished by the death penalty without law and the core components of the right to a fair trial in a process that may lead to the death penalty are peremptory.

In conclusion, in its Chapter VII action, the Security Council must respect and should not ask States to derogate from: the right to life; the right not to be tortured or to be subjected to cruel, inhuman or degrading treatment; the right not to be sentenced to the death penalty without law; and the most fundamental guarantees of the right to a fair trial when a death sentence may be imposed. In practice however, it is very unlikely that the Security Council will deliberately derogate from a jus cogens human right or adopt a resolution whose implementation necessitates that Member States derogate from such a right, for instance a resolution requiring the torture of suspected terrorists. When the

167 The fact that the right to life is not absolute does not prevent the core content of this right being peremptory. Indeed, a rule can be peremptory without its exceptions.

168 ICCPR art 6 (n 4) 174-175; Convention for the Protection of Human Rights and Fundamental Freedoms art 2 (n 110); American Convention on Human Rights art 4 (n 158) 145. 46 States party to the European Convention on Human Rights (art 2) have however ratified Protocol no 6 to the Convention for the Protection of Human Rights and Fundamental Freedoms concerning the Abolition of the Death Penalty in peacetime, and 44 States Protocol no 13 to the Convention for the Protection of Human Rights and Fundamental Freedoms, concerning the abolition of the death penalty in all circumstances.

169 The right not to be punished without law is enshrined in: ICCPR art 15 (n 4) 177; Convention for the Protection of Human Rights and Fundamental Freedoms art 7 (n 110); American Convention on Human Rights art 9 ( $n$ 158) 148. It belongs to the non-derogable rights under those treaties. Supra $\mathrm{n}$ 158. The right to a fair trial is guaranteed by: ICCPR art 14 (n 4) 176-177; Convention for the Protection of Human Rights and Fundamental Freedoms art 6 (n 110); American Convention on Human Rights art 8 (n 158) 147-148.

The Human Rights Committee, the European Court of Human Rights, and the Inter-American Court of Human Rights conclude to a violation of the right to life when the death penalty was pronounced pursuant to a process in which the right to a fair trial was not respected. UNHRC Communication no 282/1988 Leaford Smith v Jamaica (1993) UN Doc CCPR/C/47/D/282/1988 para 10.6; The Right to Information on Consular Assistancce in the Framework of the Guarantees of the Due Process of Law (1 October 1999) Inter-American Court of Human Rights Advisory Opinion OC-16/99 Series A no 16 para 135-136; Öcalan v Turkey App no 46221/99 (ECtHR, 12 May 2005) para 166.

170 Similarly, under the framework of the ICCPR, the Human Rights Committee extends the non-derogability of the right to life to the right to a fair trial when the death penalty may be imposed. 'General Comment 29 States of Emergency (Article 4)' (n 108) para 15; UNHRC 'General Comment 32 (Article 14)' (2007) UN Doc CCPR/C/GC/32 para 6. See also Irène Couzigou, 'L'incidence du droit à la vie sur le droit à un procès équitable dans la jurisprudence du Comité des droits de l'homme' (2010) 114 Revue générale de droit international public 343, 362-363. 
Security Council does not clearly demonstrate its intention to require from Member States a derogation from a jus cogens human right, there should be a presumption that the Council did not intend to impose such an obligation. Thus, Security Council resolutions should be, as far as possible, interpreted and implemented by States - or by a regional organisation to which States transferred the implementation of Security Council action - , in conformity with peremptory international human rights. ${ }^{171}$

\section{Concluding Observations}

In accordance with the analysis above, the Security Council must in principle respect human rights guaranteed in United Nations human rights treaties in force. The Security Council should also, in principle, not adopt coercive measures whose implementation by United Nations Member States, or a regional organisation, involves a derogation from those rights. Deviation from those rights, by the Security Council, Member States, or a regional organisation, in the enforcement of Security Council resolutions, without any margin of appreciation, is legal only if it is necessary for the success of the Council in maintaining or re-establishing international peace and security. The scope of the derogation must then be as minimal as possible, thus only to the extent required by the aim pursued. Furthermore, the Security Council must observe customary international human rights and should not adopt measures whose enforcement by United Nations Member States, or a regional organisation, necessitates that they depart from those rights. It must do so, unless a derogation from those (non-peremptory) rights is necessary for the maintenance or restoration of international peace and security. Such derogation must further be proportionate to the aim pursued, namely the maintenance or re-establishment of peace and security. In sum, the Security Council has a derogable obligation to respect human rights, whether they are guaranteed in United Nations human rights treaties or also in (non-peremptory) customary international law. It has also a derogable obligation not to adopt coercive measures whose implementation by Member States or a regional organisation requires that they deviate from those rights. The principle of necessity-proportionality should justify departures from human rights when the Security Council implements coercive measures or when it imposes the implementation of coercive measures to Member States. This principle also applies when Member States transferred the implementation of Security Council measures to a regional organisation. In interpreting the principle of necessity-proportionality, the Security Council should use as a model the implementation of the principle of necessity-proportionality justifying derogations from the ICCPR. Finally, the Security Council is bound by an absolute obligation to conform to those human rights that are enshrined in peremptory international law. It should also not adopt measures whose implementation by Member States or a regional organisation involves an infringement of those rights. The Security Council enjoys a broad margin of appreciation on whether and how to depart from human rights in United Nations human rights treaties in force or in (non-peremptory) customary international human rights law, and on whether and how to require a derogation from those rights by Member States. Furthermore, there are currently only a few human rights that can be

171 Case Al-Jedda (n 70). See also in favour of such a presumption Nabil Sayadi and Patricia Vinck (n 12) 36 (individual opinion of Sir Nigel Rodley (concurring)). 
considered as peremptory. Thus, in this author's opinion, the human rights standards outlined in this paper restrict the Security Council to a minimum extent.

Who could monitor observance by the Security Council of legal human rights constraints? An extensive analysis of the possibility of review of Security Council resolutions as regards international human rights limits is beyond the scope of this article. Only a few words will be said here. The International Court of Justice could pronounce, incidentally, on the legality of a Council decision concerning international human rights law in a contentious proceeding against any State. It could also assess the human rights legality of a Council measure in an advisory opinion, when the question of that legality is directly asked, or incidentally. However, this will not happen often, given the lack of compulsory contentious jurisdiction of the Court and need for a qualified majority for requesting advisory opinions. ${ }^{172}$ Furthermore, the judgment or advisory opinion, even if it will carry substantial weight, will not bind the Council. The United Nations Human Rights Committee and the United Nations Committee on Economic, Social and Cultural Rights can assess the legality of a State Member's act implementing a Security Council measure with no discretion and, at the same time, pronounce, incidentally, on the legality of the Security Council measure towards international human rights standards. These quasi-judicial organs can however not take binding decisions. As regards regional human rights bodies, such as the Inter-American Court of Human Rights and the European Court of Human Rights, or regional or domestic courts, they can also review a measure, implementing without leeway for appreciation, a Security Council resolution, for compliance with a treaty or a legal order. They can then examine, incidentally, the lawfulness of the resolution itself. ${ }^{173}$ Courts have already pronounced, incidentally, on the human rights compatibility of a Security Council measure with peremptory international human rights law. ${ }^{174}$ They may also assess the compatibility of an act of the Security Council with human rights treaties and (non-peremptory) customary international human rights law. The incidental assessment of the legality of a Security Council resolution by a regional or national court is not binding upon the Security Council. However, and this is more of a concern for the Security Council, a regional or domestic court can annul or declare illegal a measure implementing, with no latitude, a Security Council resolution, because it is in violation of human rights guaranteed under the international, or a regional or domestic, legal order. ${ }^{175}$ In doing so, the court hinders the implementation of Security Council action.

Thus, the human rights constraints of the powers of the Security Council are not meaningless simply because they are not subject to an institutionalized judicial review. Indeed, the reason for the Security Council to have to comply with human rights stan-

172 Art 36 and 65 ICJ Statute and art 96 UN Charter.

173 Nabil Sayadi and Patricia Vinck (n 12); Yassin Abdullah Kadi and Al Barakaat International Foundation $v$ Council of the European Union and Commission of the European Communities ( $\mathrm{n}$ 14); Yassin Abdullah Kadi v European Commission (n 14); European Commission, Council of the European Union, United Kingdom of Great Britain and Northern Ireland v Yassin Abdullah Kadi ( $\mathrm{n} 14$ ); Nada (n 14); Al-Dulimi and Montana Management Inc (n 14); Abousfian Abdelrazik $v$ The Minister of Foreign Affairs and the Attorney General of Canada (4 June 2009) Federal Court of Canada, 2009 FC 580.

174 Yassin Abdullah Kadi $v$ Council of the European Union and Commission of the European Communities (n 14); Youssef Nada (n 150).

175 Yassin Abdullah Kadi and Al Barakaat International Foundation v Council of the European Union and Commission of the European Communities (14); Yassin Abdullah Kadi v European Commission (14). 
dards lies in the existence of a diffuse review that can take different forms. Courts could prevent the implementation of a measure applying Security Council action. Furthermore, States (individually or collectively) may publicly criticize a Security Council resolution. They may even refuse to comply with a resolution that requires from them a departure from their human rights obligations. Thus, legal pressure (or another form of pressure) pushes the Security Council towards action that is more human rights compatible. For instance, it motivated the Security Council to amend the de-listing procedure from the then Al-Qaida and Taliban sanctions list so that it became more compatible with the right to due process. ${ }^{176}$ Therefore, in order to ensure the effective enforcement of Chapter VII action, the Security Council must conform with international human rights limits. As a political organ, the Council is not well suited to assess the legal human rights compatibility of its decisions. The same remark applies to the Security Council sanctions committees. Furthermore, the assessment of the Security Council conduct towards human rights should be uniform and coherent. Thus, in this author's view, the Security Council should give to only one organ, composed of independent human rights experts, the competence to advise it on the conformity of its contemplated action as regards international human rights standards.

\section{References}

Georges Abi-Saab, 'The Security Council Legibus Solutus? On the Legislative Forays of the Council' in Laurence Boisson de Chazournes and Marcelo Kohen (eds), International Law and the Quest for its Implementation (Brill 2010) 23.

François Alabrune, 'La pratique des comités de sanctions du Conseil de sécurité depuis 1990' (1999) 45 Annuaire français de droit international 226.

Albert Bleckmann, 'Zur Verbindlichkeit des allgemeinen Völkerrechts für internationale Organisationen' (1977) 107 Zeitschrift für ausländisches öffentliches Recht und Völkerrecht 107.

Niels Blokker, 'International Organizations and Their Members' (2004) 1 Int'L Org L Rev 139.

Marc Bossuyt, The Adverse Consequences of Economic Sanctions, E/CN 4/Sub 2/2000/33, paras 43-45.

Gian Luca Burci, 'Interpreting the Humanitarian Exceptions through the Sanctions Committees' in Vera Gowlland-Debbas (ed), United Nations Sanctions and International Law (Kluwer Law International 2001).

Gérard Cahin, La coutume internationale et les organisations internationales (A Pedone 2001).

Gérard Cahin, 'La notion de pouvoir discrétionnaire appliquée aux organisations internationales' (2003) 107 Revue générale de droit international public 535.

Antonio Cassese, International Law ( $2^{\text {nd }}$ edn, OUP 2005).

Simon Chesterman, 'UNaccountable? The United Nations, Emergency Powers, and the Rule of Law' (2009) 42 Vand J Transnat'I L 1509.

Paul Conlon, 'The Humanitarian Mitigation of UN Sanctions' (1996) 42 German Yearbook of International Law 249.

Irène Couzigou, 'L'incidence du droit à la vie sur le droit à un procès équitable dans la jurisprudence du Comité des droits de l'homme' (2010) 114 Revue générale de droit international public 343.

Irène Couzigou, 'La lutte du Conseil de sécurité contre le terrorisme international et les droits de I'homme' (2008) 1 Revue générale de droit international public 49.

Wladyslaw Czaplinski, 'Jus Cogens and the Law of Treaties' in Christian Tomuschat \& Jean-Marc Thouvenin (eds), The Fundamental Rules of the International Legal Order (Nijhoff 2006).

176 SC Res 1904 (17 Dec 2009) UN Doc S/RES/1904.

After ' $[t]$ aking note of challenges, both legal and otherwise, to the measures implemented by Member States under [the 1267 regime]' (at 9th preamble), the Council establishes an 'Office of the Ombudsperson' (at 20). SC Res 1989 (17 June 2012) UN Doc S/RES/1989 (improving the fairness of the listing procedure). 
Eric David, 'Le droit international applicable aux organisations internationales' in Dony Marianne (ed), Mélanges en hommage à Michel Waelbroeck (Bruylant 1999).

Erika de Wet, The Chapter VII Powers of the United Nations Security Council 182 (Hart Publishing 2004).

Erika de Wet, 'The Role of Human Rights in Limiting the Enforcement Power of the Security Council: A Principled View' in Erika de Wet \& André Nollkaemper (eds), Review of the Security Council by Member States (Intersentia 2003).

Emmanuel Decaux, 'De la promotion à la protection des droits de I'homme' in Société française de droit international (ed), La protection des droits de l'homme et l'évolution du droit international: actes du colloque de Strasbourg de 1997 (A Pedone 1998).

Christian Dominicé, 'Le Conseil de sécurité et le droit international' in Jeanne Belhumeur \& Luigi Condorelli (eds), L'ordre juridique international entre tradition et innovation (Presses Universitaires de France 1997).

Oliver Dörr, 'Article 31' in Oliver Dörr and Kirsten Schmalenbach (eds), Vienna Convention on the Law of Treaties (Springer 2012).

Berhnhard Ehrenzeller, Marco Sassoli, Walter Stoffel, Beatrice Wagner Pfeifer (eds), Human Rights, Democracy and the Rule of Law (Dike 2007).

Bardo Fassbender, 'Sources of human rights obligations binding the UN Security Council' in Peter HF Bekker, Rudolf Dolzer \& Michael Waibel (eds), Making Transnational Work in the Global Economy (CUP 2010).

Bardo Fassbender, 'Targeted Sanctions and Due Process' (2006) 1, <www.un.org/law/counsel/ Fassbender_study.pdf> accessed 14 June 2016.

Judith G Gardam, 'Legal Restraints on Security Military Enforcement Action' (1995-1996) 17 Mich J. Int'I L. 285.

Tarcisio Gazzini, 'Personality of international organizations', in Jan Klabbers \& Asa Wallendahl (eds), Research Handbook on the Law of International Organizations (Elgar 2011).

Terry D Gill, 'Legal and Some Political Limitations on the Power of the UN Security Council to Exercise its Enforcement Powers Under Chapter VII of the Charter' (1995) 26 NYIL 33.

Vera Gowlland-Debbas, 'Security Council Enforcement Actions and Issues of State Responsibility' (1994) 43 ICLQ 55.

Lauri Hannikainen, Peremptory Norms (Jus Cogens) in International Law (Lakimiesliiton Kustannus 1988).

Matthias J Herdegen, 'The 'Constitutionalization' of the UN Security System' (1994) 27 Vand J Transnat'l L 135.

Eric Hoskins, 'The Humanitarian Impacts of Economic Sanctions and War in Iraq' in Thomas George Weiss et al (eds), Political Gain and Civilian Pain (Rowman \& Littlefield 1997).

Hans Kelsen, The Law of the United Nations (Stevens \& Sons Limited 1950).

Robert Kolb, La bonne foi en droit international public (Presses Universitaires de France 2000).

Robert Kolb, Théorie du jus cogens international (Presses Universitaires de France 2001).

Robert Kolb, Gabriel Porretto and Sylvain Vité, L'application du droit international humanitaire et des droits de l'homme aux organisations internationales (Bruylant 2005).

Alexandros Kolliopoulos, 'Les comités des sanctions de I'Organisation des Nations Unies' in Laura Forlati \& Linos-Alexandre Sicilianos (eds), Economic Sanctions in International Law (Nijhoff 2014).

Marti Koskenniemi, Fragmentation of International Law: Difficulties Arising from the Diversification and Expansion of International Law (13 April 2006), para 331, UN Doc A/CN4/L 682.

Markus Kotzur, 'Good Faith (Bona Fide)' in Rüdiger Wolfrum (ed), Max Planck Encyclopedia of Public International Law (2 ${ }^{\text {nd }}$ edn, North-Holland 2012).

Nico Krisch, 'Article 39' in Bruno Simma et al (eds), The Charter of the United Nations ( ${ }^{\text {rd }}$ edn, OUP 2012) vol II.

Nico Krisch, 'Introduction to Chapter VII: The General Framework' in Bruno Simma et al (eds), The Charter of the United Nations ( $3^{\text {rd }}$ edn, OUP 2012) vol II.

Evelyne Lagrange, 'Le Conseil de sécurité des Nations Unies peut-il violer le droit international?' (2004) 37 Revue belge de droit international 568. 
Dominic McGoldrick, 'The Interface between Public Emergency Powers and International Law' (2004) 2 International Journal of Constitutional Law 380.

Frédéric Mégret and Florian Hoffmann, 'The UN as a Human Rights Violator? Some Reflections on the United Nations Changing Human Rights Responsibilities' (2003) 25 Hum Rts Q 314.

Christopher Michaelsen, 'Human Rights as Limits for the Security Council: A Matter of Substantive Law or Defining the Application of Proportionality?' (2014) 19 Journal of Conflict \& Security Law 451.

Manfred Nowak, UN Covenant on Civil and Political Rights (NP Engel 2005).

Stefan Oeter, 'Ius cogens und der Schutz der Menschenrechte' in Stephan Breitenmoser, Berhnhard Ehrenzeller, Marco Sassoli, Walter Stoffel, Beatrice Wagner Pfeifer (eds), Human Rights, Democracy and the Rule of Law (Dike 2007).

Gabriel H Oosthuizen, 'Playing the Devil's Advocate: the United Nations Security Council is Unbound by Law' (1999) 12 LJIL 549.

Jaime Oraa, Human Rights in States of Emergency in International Law (Clarendon Press 1992).

Alexander Orakhelashvili, Peremptory Norms in International Law (OUP 2006).

Alexander Orakhelashvili, 'The Impact of Peremptory Norms on the Interpretation and Application of United Nations Security Council Resolutions' (2005) 16 EJIL 59.

Andreas L Paulus, 'Jus Cogens in a Time of Hegemony and Fragmentation' (2005) 74 Nord J Intl L 297.

Andreas L Paulus \& Johann Ruben Lei $\beta$, 'Article 103' in Bruno Simma et al (eds), The Charter of the United Nations ( $3^{\text {rd }}$ edn, OUP 2012) vol II.

Alain Pellet, 'Rapport introductif: peut-on et doit-on contrôler les actions du Conseil de sécurité?' in Société française de droit international (ed), Chapitre VII de la Charte des Nations Unies: actes du XXVIIIe colloque de Rennes, 2 au 4 juin 1994 (A Pedone 1995).

René Provost, 'Starvation as a Weapon: Legal Implications of the United Nations Food Blockade Against Iraq and Kuwait' (1992) 30 Colum J Transnat'l L 577.

August Reinisch, 'Developing Human Rights and Humanitarian Law Accountability of the Security Council for the Imposition of Economic Sanctions' 95 (2001) AJIL 851.

Ruth B Russel, A History of the United Nations Charter (The Brookings Institution 1958).

Henry G Schermers and Niels M Blokker, International Institutional Law ( $5^{\text {th }}$ edn, Martinus Nijhoff 2011).

David Schweigman, The Authority of the Security Council under Chapter VII of the UN Charter (Kluwer Law International 2001).

Scott Sheeran \& Catherine Bevilacqua, 'The UN Security Council and international human rights obligations' in Scott Sheeran \& Nigel S Rodley (eds), Routledge Handbook of International Human Rights Law (Routledge 2013) 371.

Linos-Alexandre Sicilianos, Les réactions décentralisées à l'illicite (Librairie générale de droit et de jurisprudence 1990).

Rhona KM Smith, International Human Rights (6 $6^{\text {th }}$ edn, OUP 2014).

Dorothee Starck, Die Rechtmäßigkeit von UNO-Wirtschaftssanktionen in Anbetracht ihrer Auswirkungen auf die Zivilbevölkerung (Duncker \& Humblot 2000)136-137.

Frédéric Sudre, Droit européen et international des droits de l'homme (PUF 2015).

Eric Suy, 'The Concept of Jus Cogens in Public International Law' in Carnegie Endowment for International Peace/European Centre (ed), The Concept of Jus Cogens in International Law (Carnegie Endowment for International Peace 1967).

Paul Tavernier, 'L'identification des règles fondamentales, un problème résolu? Jus cogens and obligation erga omnes' in Christian Tomuschat \& Jean-Marc Thouvenin (eds), The Fundamental Rules of the International Legal Order (Nijhoff 2006) 1.

Djacoba Liva Tehindrazanarivelo, 'Le droit des Nations Unies et les limites au pouvoir de sanction du Conseil de sécurité' in Laura Forlati and Linos-Alexandre Sicilianos (eds), Economic Sanctions in International Law (Nijhoff 2014).

Gerhard Thallinger, 'Sense and Sensibility of the Human Rights Obligations of the United Nations Security Council' (2007) 67 Zeitschrift für ausländisches öffentliches Recht und Völkerrecht 1015.

Christian Tomuschat, Human Rights ( $3^{\text {rd }}$ edn, OUP 2014). 
Antonios Tzanakopoulos, 'Collective Security and Human Rights' in Erika de Wet \& Jure Widmar (eds), Hierarchy in International Law (OUP 2012).

Antonios Tzanakopoulos, Disobeying the Security Council (OUP 2011).

Daniel-Henri Vignes, 'Le principe de l'unanimité dans les organisations européennes' (1955) I Annuaire français de droit international 111.

Devon Whittle, 'The Limits of Legality and the United Nations Security Council: Applying the ExtraLegal Measures Model to Chapter VII Action' (2015) 26 EJIL 671.

Rüdiger Wolfrum, 'Article $1^{\prime}$ in Bruno Simma et al (eds), The Charter of the United Nations ( $3^{\text {rd }}$ edn, OUP 2012).

Elisabeth Zoller, La bonne foi en droit international public (A Pedone 1977). 